NBER WORKING PAPER SERIES

\title{
HAMAS, TALIBAN AND THE JEWISH UNDERGROUND: AN ECONOMIST'S VIEW OF RADICAL RELIGIOUS MILITIAS
}

\author{
Eli Berman \\ Working Paper 10004 \\ http://www.nber.org/papers/w10004 \\ NATIONAL BUREAU OF ECONOMIC RESEARCH \\ 1050 Massachusetts Avenue \\ Cambridge, MA 02138 \\ September 2003
}

I appreciate the comments of Laurence Iannaccone, Timur Kuran, Bradley Ruffle and my colleagues at Boston University, Rice University and the University of California San Diego, as well as the comments of participants in conferences of the National Bureau of Economic Research, the Society for the Scientific Study of Religion and the New England Universities Development Conference, and the comments of participants in numerous seminars. This project is supported by National Science Foundation grant $\# 0214701$ through the National Bureau of Economic Research. Mistakes are my own. The views expressed herein are those of the authors and are not necessarily those of the National Bureau of Economic Research.

(C2003 by Eli Berman. All rights reserved. Short sections of text, not to exceed two paragraphs, may be quoted without explicit permission provided that full credit, including $(\mathbb{C}$ notice, is given to the source. 
Hamas, Taliban and the Jewish Underground: An Economist's View of Radical Religious

Militias

Eli Berman

NBER Working Paper No. 10004

September 2003

JEL No. D2, H41, J0, M5, N4, O17, Z13

\begin{abstract}
Can rational choice modeling explain destructive behavior among the Taliban, Hama and other radical religious militias? This paper proposes a club good framework which emphasizes the function of voluntary religious organizations as efficient providers of local public goods in the absence of government provision. The sacrifices which these groups demand are economically efficient (as in Iannaccone (1992)) and make them well suited for solving the extreme principalagent problems present in militia production. Thus the analysis can explain why religious radicals create such effective militias. Seemingly gratuitous acts of violence by group members destroy their outside options, increasing the incentive compatibility of loyalty. The analysis has clear implications for economic policy to contain militias.

Eli Berman

Department of Economics

UC San Diego

9500 Gilman Drive

La Jolla, CA 92093-0508

and NBER

elib@ucsd.edu
\end{abstract}




\section{“We must examine the costs and benefits of continued armed operations."}

M. Al Zahar, a Hamas leader, quoted in Al Quds, (East Jerusalem: October 1995). ${ }^{2}$

\section{INTRODUCTION}

The Taliban, Hamas and other radical Islamic groups present a challenge to behavioral scientists who assume rational choice in individual decisions. How do we explain destructive acts from which individuals derive no direct benefit such as subjugation and institutional abuse of women, minorities and homosexuals, closing of schools and hospitals, enforcement of general strikes, abuse and murder of prisoners, or desecration of holy sites? Why do radical religious sects so often turn to militia activity, and why are their militias so effective?

Members of these radical religious groups are hardly your typical "bad guys." They exhibit productive, constructive and noble behaviors: acts of piety, charity and self-sacrifice. The same organizations are also remarkably efficient providers of valuable local public goods. The Taliban restored law and order to Afghanistan, halting poppy cultivation (for opium) and reducing crime. By securing trade routes they restored commerce (both legal and illegal) in Afghanistan. Both the Taliban and Hamas' parent organization, the Muslim Brotherhood reduce drug addiction among members. The Muslim Brotherhood provides health care, schooling, welfare and community services to needy communities in Gaza and the West Bank. The Brotherhood is so efficient and honest that it was often used by humanitarian agencies to distribute aid in the West Bank and Gaza.

Are these extreme, violent, behaviors due to powerful entrenched ideologies which form preferences? That argument is weakened by sharp shifts in declared ideology and behavior. The Taliban in 1994 were nonviolent clerics concerned with personal piety and replacing violent warlords with local Islamic government. By 1996 they were a militia bent on conquering Afghanistan and by 2001 they were so committed to international Jihad that they destroyed their accomplishments in a doomed effort to protect Al Qaeda. The Muslim Brotherhood in Palestine was a nonviolent group dedicated to an agenda of personal piety and local Islamic government till they created Hamas and embarked on a violent, nationalist territorial struggle. More generally, the sanctification of political violence as Jihad by radical Islam is a recent phenomenon, a break with mainstream Muslim theology (Black, 2001, p. 338). ${ }^{3}$

Also remarkable is that, once formed, both Hamas and Taliban became remarkably efficient militias. The Taliban, who were not experienced fighters, managed to conquer and hold

${ }^{2}$ Mishal and Sela (2000), p. 71.

${ }^{3}$ Political violence with a religious justification by sects has a long history in Islam, as in other monotheistic religions (see below). It was widely denounced when it reappeared in Egypt in the mid $20^{\text {th }}$ century. 
most of Afghanistan, an accomplishment unmatched by even the Soviet military. The Hamas quickly evolved into an effective terrorist organization, difficult to infiltrate and more effective than its secular rival, the PLO's Tanzim, or than the more experienced Islamic Jihad. ${ }^{4}$

This paper attempts to resolve all those puzzles at once, using an approach which assumes rational choice by individuals. Rationalization is not merely a methodological goal but has a practical implication. If we cannot explain these destructive behaviors in a model in which individuals respond to incentives, what policy solutions could we recommend that are not themselves inherently destructive? ${ }^{5}$

I use a "club-good" approach to model radical religious groups. Imagine a community for which neither government nor markets function well. Local public goods usually provided by government such as public safety, law and order and welfare services are poorly provided or absent, while neither public nor private sectors efficiently deliver education, health services or insurance. It would not be surprising for individuals in such a place to band together into communities which provide public safety, education, welfare services, and other local public goods through mutual insurance (as documented by Townsend (1994), for instance).

Iannaccone (1992) pointed out that religion is a natural organizing node for community provision of local public goods. Moreover the most puzzling features of religious sects, their propensity to limit choices (prohibitions) and to destroy resources and options (sacrifices), can be explained by the internal distortions due to a club's efficient provision of services to members. Since club members engage in joint production of local public goods during their hours of nonmarket time, market work is a distraction with a negative externality for other members. So efficient clubs should tax market wages. Lacking tax authority they might turn to prohibitions on consumption as a crude but feasible way of lowering wages. Sacrifices can be explained as a costly signal of "commitment" to the community, or (less prosaically) a signal of relatively poor economic options outside the club which are efficient in the presence of heterogeneity in economic opportunities. A sacrifice is then an initiation rite allowing membership and with it access to club goods.

Iannaccone provides supporting evidence for the club model from data on Christian denominations, showing that the more extreme the prohibitions and sacrifices, the greater the provision of public goods to members. Berman (2000) extends that argument in an application to Ultra-Orthodox Jews, showing that subsidies to sects dramatically increase distortion of incentives. Among Israeli Ultra-Orthodox Jews subsidies caused fertility to increase by over a child per woman and duration of Yeshiva (full time religious seminary) attendance to increase by over10 years, all within two decades. Berman and Stepanyan (2003) provide further evidence of high fertility and generally low returns to schooling among Muslim sects in five countries.

${ }^{4}$ For evidence of the Hamas' effectiveness at suicide attacks see Berman and Laitin (2003).

${ }^{5}$ The late Ehud Sprinzak emphasized the importance of rational choice models of terrorism (Sprinzak, 2000) for policymaking. 
This paper makes two further analytical points. First, religious clubs are well suited to running militias. Militias are crucially sensitive to defection. Thus a club which extracts signals of commitment has an advantage in militia activity. The analysis evokes Becker's theory of rational crime (Becker, 1968), in that individuals weigh the benefits of remaining loyal to or defecting from behavioral norms, with the twist that the norms may be those of an illegal militia. Second, apparently gratuitous acts of destruction can both signal commitment and reinforce incentive compatibility, extending the ability of the club to provide militia services to members. Thus, cruel and apparently meaningless destruction may be rational and efficient for a militia.

Anticipating the results, the key policy implication of this analysis is that an efficient economy and a secular state providing public goods both weaken religious sects as members become less desperate for the economic services these sects provide. That process compromises the ability of sects to run militias. This paper is not about Al Qaeda, but the reader might well wonder if economics can really be that important --the September $11^{\text {th }}$ terrorists were educated and far from poor. Yet those terrorists were not typical members. One would hardly expect $\mathrm{Al}$ Qaeda to send some of its' thousands of semi-literate mercenaries in Afghanistan to flight school in Florida if disaffected students in Europe were available. The general point is that a club which is strengthened by its ability to provide local public goods in a failed state with a failed economy, like Afghanistan, may attract members for a number of reasons. It could then select leaders and combatants from among those members according to characteristics other than poverty.

Though radical Islamic militias motivate the discussion, there is nothing inherently Muslim about the model. Militia activity among religious sects dates back at least to the Middle Ages, when the Templar Knights and the Hospitaler Knights organized as orders to conquer the holy land during the Crusades. ${ }^{6}$ The analysis is also applied to the "Jewish Underground," a terrorist organization of Orthodox Jewish settlers on the West Bank in the early 1980s. The model explains their demise as an example of a militia that overstepped its reach, violating an incentive compatibility condition by taking on a project too destructive for its base of support.

The next section provides background on the Taliban and Hamas, highlighting the common puzzles and drawing parallels. Section III reviews the club model for a religious sect, extending it to explain militias by developing a militia production function. Section IV applies that model to explain the jarring combination of efficiency, piety and destructiveness in these groups. Section VI considers the Jewish Underground and other radical religious militias. Section VII considers policy implications and section VIII concludes.

\footnotetext{
${ }^{6}$ Like the Taliban and Hamas they had strict prohibitions and sacrifices, including vows of celibacy, for instance. These groups also underwent an agenda drift. Long after the Crusades, the Templars were still running fiefdoms in much of France, till they were finally suppressed by the King. I thank Dagobert Brito for pointing out this historical analogy.
} 


\section{TALIBAN AND HAMAS: BACKGROUND}

\section{Radical Islam}

The Taliban and Hamas are both highly ritualistic, extremely conservative Muslim groups. They belong to a family of radical sects whose religious behavior represents a clear break from traditional practice. They augment the prohibitions of traditional Islamic practice, such as dress codes and shaving. They tend to segregate themselves from other Muslims and to be extremely intolerant of deviation, in contrast to the tolerance of traditional Islam. Though often termed "fundamentalist" - as if returning to some historic norm of practice, these groups actually practice norms unprecedented in their extremism. Radical Islam dates back only to the 1920s with the establishment by al-Banna of the Muslim Brotherhood in Egypt and Mawdudi's subsequent founding of the Jamaat-al-Islami in Pakistan.

Radical Islamists are an example of a group whose core beliefs clash with those of Western liberalism in their view of an individual's place within society. In the Western liberal approach individuals have rights and obligations in a direct relationship with the state. ${ }^{7}$ In contrast, Radical Islam emphasizes a more historic approach in which an individual's primary relationship is with a clan, sect or tribe, and through that with the state [Black (2001), p. 309]. Ties that might undermine that relationship are viewed with suspicion.

Those strong historical affiliations with clans, sects and tribes are not surprising if government is a poor provider of local public goods such as health care, education and public safety and if the market is an inefficient provider of income and insurance. In that environment, group affiliation is a source of mutual insurance, providing protection, health care, income, food, clothing and the like. Though money need not change hands that insurance relationship is nonetheless economic. ${ }^{8}$ Such relationships with a group much smaller than the state government must have been ubiquitous historically. They survive in the West in the form of radical religious sects like Ultra-Orthodox Jews and Christian Anabaptists (such as Hutterites and Mennonites) who provide extremely high levels of community mutual aid to members.

An efficient market economy and a functioning secular state are both threats to these affiliations as they reduce the need for the services which these groups provide and reduce the nonmarket hours available to members to provide services to others. Like Radical Islam, radical Christian and Jewish sects often seek to distance members from market economies.

\footnotetext{
${ }^{7}$ Public Finance, in this tradition, designs policy for states in relationship to individuals, not groups.

${ }^{8}$ Ben-Porath [1980] emphasizes nonmarket exchange in his "F-connection" approach to Sociology.
} 


\section{Taliban}

Afghanistan is a famously ungovernable country which has suffered 23 years of civil war at an appalling cost of one and a half million lives. ${ }^{9}{ }^{10}$ The Mujaheddin, a loose tribe-based alliance of Islamic militants conducted a successful insurgency which eventually expelled a Soviet occupation. They had U.S. and Saudi aid, administered by Pakistani intelligence (ISI). Those subsidies were remarkably effective in expelling the Soviets, but radicalized Afghani society

"Prior to the war the Islamicists barely had a base in Afghan society, but with money and arms from the CIA pipeline and support from Pakistan, they built one and wielded tremendous clout." [Rashid (2000), p. 19].

By the mid 1990s, the Pashtun south had collapsed economically. ${ }^{11}$ It was run by former Mujaheddin warlords in warring fiefdoms ranging in size from a few provinces to single villages. During this particularly chaotic period, the Taliban emerged in Kandahar, the largest city in the Pashtun south. Rashid (2000) emphasizes economic factors contributing to their formation.

"International aid agencies were fearful of even working in Kandahar as the city itself was divided by warring groups. Their leaders sold off everything to Pakistani traders to make money, stripping down telephone wires and poles, cutting trees, selling off factories, machinery and even road rollers to scrap merchants. The warlords seized homes and farms, threw out their occupants and handed them over to their supporters. The commanders abused the population at will, kidnaping young girls and boys for their sexual pleasure, robbing merchants in the bazaars and fighting and brawling in the streets." [Rashid, (2000), p. 21]

Banditry on the roads was an expensive obstacle for smugglers. Truckers based in the Pakistani border city of Quetta had a long tradition smuggling goods through Afghanistan to Iran, Turkmenistan and the rest of Central Asia. Their route from Quetta passed north through Kandahar then west through the Afghan city of Herat, which was controlled by the militia of Ismael Khan. With alternate routes in northern Afghanistan blocked by heavy fighting, this route seemed the best chance for trade from Pakistan to Iran and Turkmenistan and on into Turkey. By

\footnotetext{
${ }^{9}$ Rashid (2000), and Davis (1999) describe the Afghan civil war and the rise of the Taliban.
}

${ }^{10}$ In 1978 a Marxist coup from within the army overthrew a Soviet backed government. Rural tribes declared a holy war against the coup leadership. A violent power struggle within the coup culminated in the assassination of the new President and in the Soviet invasion of December 1979. Over the next ten years the Mujaheddin conducted a successful guerrilla war which eventually forced a Soviet retreat, despite a $\$ 45 \mathrm{~B}$ military effort. The Mujahheddin received about $\$ 10 \mathrm{~B}$ in military support, mostly from the U.S. and Saudi Arabia, in an effort largely administered by Pakistani intelligence (ISI). (Cost figures from Huntington [1996]).

${ }^{11}$ The Soviet-backed president was overthrown in 1992 when Kabul, the capital, fell to an alliance of Mujaheddin from northern Afghani Tajik and Uzbek tribes. This set off a bloody internal war with a coalition of Pashtun tribes over Kabul, which had been under Pashtun control for 300 years. In 1994 General Dostum, leader of the northern Uzbeks, defected to join these Pashtun and their leader, Hikmetyar. Yet even with Pakistani backing Hikmetyar could not seize Kabul. 
the fall of 1994 the Pakistani government backed an effort by the ISI to reconstruct roads and create alliances along the Kandahar-Herat route. ${ }^{12}$

In October 1994 the ISI sent a trial convoy loaded with medicine from Quetta to Ashkabad, in Turkmenistan. When the convoy was held up by warlords south of Kandahar, a small, largely unknown group of radical Islamists, the Taliban, conveniently emerged to free it. The Taliban were well-armed with rifles, mortars, ammunition and vehicles they had ostensibly acquired by raiding an ammunition dump two weeks earlier on the Pakistani border. By December the Taliban were operating a safe single-toll road through the Kandahar region. Precisely what the Kandahar warlords had previously failed to offer the ISI. Convoys safely passed from Turkmenistan to Quetta and back for the first time in years.

The same evening the convoy was liberated, those few hundred Taliban captured Kandahar with minimal casualties. The second biggest city in Afghanistan was taken by simply bribing the local warlords to surrender. By December they had recruited 12,000 students from the religious schools of the radical Islamic Juma'at al Islamiya (JUI) of Pakistan, mostly from Afghan refugee families. Within three months the Taliban had efficiently conquered 12 of 31 provinces of Afghanistan, largely through a series of Coasian bargains with local warlords. They collected arms, imposed law and order, and opened roads. ${ }^{13}$ The resulting increase in commerce immediately lowered the price of food. ${ }^{14}$

The rest of the story is familiar: The Taliban proceeded to conquer and control some $90 \%$ of Afghanistan, a feat unmatched by the Soviet Union. Smuggling prospered so much that it caused a \$400m drop in Pakistani customs revenue between 1993 and 1997. (Rashid, p. 192). The Taliban protected most of the $\$ 1 \mathrm{~B}$ Afghan-Pakistani drug trade. Their control was so complete that they could eventually ban the cultivation of opium in 2000. (Note that the Taliban banned cultivation but allowed trade in opium and heroin to continue.)

\section{The puzzle of gratuitous destruction}

Beyond effectively providing law and order the Taliban instituted a set of extreme policies so destructive that they challenge the notion of rational choice:

"The Taliban immediately implemented the strictest interpretation of Sharia law ever seen in the Muslim world. They closed down girls' schools and banned women from working outside the home, smashed TV sets, forbade a whole array of sports and recreational activities and ordered all males to grow long beards." (Rashid, p. 30.)

\footnotetext{
${ }^{12}$ Rashid (2000) reports that In October 1994 Pakistani Prime Minister Bhutto met with Ismael Khan of Herat and Uzbek warlord General Dostum, to negotiate a secure route (p. 27). Davis (1999), relying on several sources, also emphasizes the role of Pakistani economic interests in the formation of the Taliban.

${ }^{13}$ The Taliban's version of their movements' birth stresses not safe roads but public safety of another kind. They claim to have been a group of seminary students, led by Mullah Omar, a Mujahhedin veteran, who were enlisted by the local population to prevent the rape of teenage girls and boys by warlords.

${ }^{14}$ Rashid 2000, p. 35.
} 
These practices are inconsistent with traditional Islam. Mohammed is known for emancipating women. They were also much more extreme than restrictions imposed on women in the Taliban's home communities in the Pashtun region around Kandahar.

The subjugation of women and non-Taliban worsened as they amassed power and moved into regions outside the Pashtun south. In the major cities of Kabul and Herat, norms and Sharia law were enforced with outrageous aggressiveness -women were beaten for wearing shoes that squeaked. Foreign aid workers were bullied into leaving, causing a shutdown of schools, clinics and humanitarian aid. Why would a movement trying to further a religious agenda among Muslims distance those same Muslims by abusing them?

Of all the allies that the ISI could have (and did) chose, why is it that the group with the most extreme religious practices was the most efficient at securing the safety of convoys and ordinary people, and at conquering and controlling Afghanistan?

\section{Hamas}

Just as the Taliban militia are an offshoot of the nonviolent JUI, the Hamas is a direct descendant of the Muslim Brotherhood, the first modern radical religious movement in Islam. ${ }^{15}$ The Muslim Brotherhood was founded by Hasan al-Banna in Egypt in 1928 with the aim of reinvigorating Islam through individual piety and self-improvement, fighting the insidious force of assimilation into materialist Western culture, and the establishment of an Islamic state. Members met weekly in small groups, reinforcing a set of basic prohibitions on gambling, alcohol, adultery and usury. The Brotherhood established a broad network of mosques, boys and girls schools, youth groups, clinics, hospitals, charities, trade unions, night schools for workers, and even factories. These enjoyed considerable public support both as a social service provider and as a focus of religious and political expression.

In 1948 a splinter terrorist organization of the Brotherhood, the "Secret Apparatus," (alJihaz al sirri) carried out a campaign of bombing and political assassination, including the assassination of the Egyptian Prime Minister. The government subsequently suppressed the Brotherhood. Al-Banna was shot in the street, apparently by a government agent. Since then the Muslim Brotherhood has been an illegal but tolerated force in Egyptian society and politics, sometimes courted by government but often suppressed. In the 1950s an imprisoned member, Sayyid Qutb, developed the militant ideology of radical Islam. He preached that religious communities could only survive if segregated from secular culture. Moreover, Qutb preached that violent revolt was a religious duty, both against the secular West and against the secular government of Egypt. ${ }^{16}$ His call to violence broke sharply with traditional Muslim theology,

${ }^{15}$ Armstrong (2000) provides a clear account of the history of the Society of Muslim Brotherhood.

${ }^{16}$ This interpretation of the religious requirement of Jihad is controversial. Jihad can also mean simply a personal struggle for piety, self-improvement and the service of others (Esposito, 2002, p. 27). 
which is tolerant of other cultures, permits warfare only in self-defense and rejects violence in religious matters. ${ }^{17}$

Branches of the Muslim Brotherhood appeared in the Gaza and the West Bank in the 1950s. In 1971 Sheikh Ahmed Yassin founded an affiliated organization called Congress (Mujamah) in Gaza. Muslims in the West Bank and Gaza were relatively secular at the time, but Sheikh Yassin soon gained popular support for his movement by establishing a social service network of medical clinics, schools, charities, support for orphans, drug treatment centers, youth clubs, sports clubs and mosques. ${ }^{18}$ The Congress filled gaps in the social services provided by the Israeli occupational government, charities and international organizations, especially among refugees. Congress was financed by tithing (zakat) and by support from Arabs abroad. ${ }^{19}$

Yassin's Congress shared Al-Banna's agenda: personal ethical conduct, personal piety and the eventual establishment of a local Islamic government. In contrast to their secular rival, the Palestinian Liberation Organization (PLO), the Brothers saw the liberation of Palestine as a long term goal to be deferred till ethical conduct and local Islamic government were established. The Brothers were nonviolent, except for some skirmishes with PLO supporters. They contributed to an increase in religious practice in the 1980s in the West Bank and Gaza: dress codes were more stringently observed and outward signs of piety increased, including the frequency of prayer. The increased stringency of practice was especially evident in Gaza which is poorer and where the Brothers have more support and institutions.

Hamas was founded in1988 as a result of the first Palestinian Intifada, a spontaneous revolt against Israeli occupation, led by neither the PLO nor the Brothers. ${ }^{20}$ SheikhYassin's local organizers urged him to endorse the revolt and establish a militia, lest the Brothers lose popular support to the local leadership of the PLO, which was harnessing the outburst of nationalism. Yassin initially resisted but eventually agreed to establishing an affiliated secret militia, the Hamas, carefully separating it from the Congress to protect the Brotherhood's social service institutions from reprisal. ${ }^{21}$

\footnotetext{
${ }^{17}$ See Armstrong (2000), pp. 241-243. Qutb and his supporters argue that Islam is under siege so that violent revolt is an act of self-defense. I thank Timur Kuran for pointing this out.

${ }^{18}$ Mishal and Sela (2000), Juergensmeyer (2000), p. 78.

${ }^{19}$ Armstrong (2000), p. 351. The Hamas would eventually have a leadership in exile in the U.S. which raised funds among the Palestinian diaspora as well. The Israel Security Agency estimated foreign support at about one million dollars per month in the Spring of 2003, following international pressure on donors to stop that support. "Only a fraction" of those funds go to the military wing (ISA director Avi Dichter, Ha'Aretz, July 4, 2003).

${ }^{20}$ Schiff and Ya'ari (1989).

${ }^{21}$ The Lebanese Shi' ite organization Amal similarly insulated itself from reprisal by establishing Hizbullah as a separate entity.
} 
The Hamas immediately began printing leaflets calling for violent opposition to the Israeli occupation. It underwent an ideological shift, adopting a nationalist position more extreme than that of the PLO, making the immediate conquest of all of Palestine (as opposed to just the West Bank and Gaza) a religious obligation. This was an expensive change in ideology, as it predictably provoked a campaign of arrest and suppression by the Israeli army which put members at high risk of arrest. That ideological shift would eventually also put members at risk of arrest and reprisal by the PLO after the Oslo accords.

The Hamas soon became a singularly effective militia: hard to penetrate, disciplined, adequately funded, well trained and committed. Members regularly risked arrest and endangered their lives by confronting soldiers, assassinating collaborators, organizing and carrying out terrorist attacks. Hamas suicide bombings of buses in Israel in 1996 delivered a close Israeli election to the right wing Likud party, critically injuring the Oslo process which Hamas opposed. To this day Hamas boasts the highest proportion of suicide bombers who carry out their objective or at least die trying. Their attacks are also the most deadly among Palestinian terrorist groups. ${ }^{22}$

Besides their remarkable agenda shift and their effectiveness as a militia, the Hamas also present a third puzzle: a tendency to make increasing demands of members and to inflict gratuitous punishment on nonmembers which is puzzling for a populist movement. Beginning with the first Intifada, they forced a poor population to adhere to general strikes of commercial activity which prevented Palestinians from shopping, doing business and sometimes even from working. They even attempted a boycott on all work for Israelis, which would have resulted in sacrificing perhaps a quarter of Palestinian GNP. ${ }^{23}$ They worked to cripple a peace process that was returning occupied territory to Palestinian control because the process represented in their view collaboration with the conquerors of Palestine in 1948, precisely the opposite of the patient ideology of the pre-1988 Muslim Brotherhood.

\section{Taliban and Hamas}

To summarize, the Taliban and Hamas are both radical Islamic groups that turned violent. While their geographical and theological origins are distinct, they share several functional characteristics which suggest investigating their behavior in parallel, as summarized in Table I. Both movements arose in environments with weak local government and responded by providing a local public good. Both are militias that formed as affiliates of venerable nonviolent radical Islamic organizations, the Hamas from the Islamic Brotherhood and the Taliban from the Jamiate-Ulema-Islam (JUI) in Pakistan. Both received generous subsidies from abroad, either for ideological reasons or in return for services. Both underwent increases in stringency of practice as they gained power. Younger members undergo some costly initiation rite of personal sacrifice

${ }^{22}$ Berman and Laitin (2003).

${ }^{23}$ That boycott failed in 1988 though the goal was later indirectly achieved. Attacks led Israel to replace Palestinians with foreign laborers in the 1990s and to severely restrict their access to Israeli labor markets in 2001. 
in each group. Both groups changed their ideologies drastically and at great cost to members. Both developed into militias which produced local public goods using violence. These similarities should not be overstated. One difference is that the Hamas view most Palestinians as potential members while the Taliban seem to see most Afghans as a conquered people.

While this paper limits itself to the Taliban, Hamas and Jewish Underground (below) whose evolution is recent and relatively well documented, that general set of characteristics may well be shared by other religious militias, a point we return to below. Concentrating on the functional characteristics of these groups avoids a discussion of their legitimacy as religious or national liberation movements. (The economic model has nothing to add to a discussion of legitimacy.)

\section{EfFicient Prohibitions ANd SACRIfiCE ${ }^{24}$}

\section{Prohibitions and sacrifices among religious groups in general}

Before tackling the puzzles of radical religious groups and their militias, even mainstream religious groups constitute a puzzle for rational choice theory: these groups prohibit common pleasurable behaviors and require sacrifices. Prohibitions include dietary restrictions, Sabbath observance, dress codes, head shaving, fidelity, driving licenses, restriction of sexual practices and refusal of medical care, for instance. Sacrifices are irreversible destruction of resources, such as burnt offerings. In the recent history of European Jewry, a circumcision irreversibly labeled a child as Jewish, an act that might put his life at risk by destroying the option of pretending to be a gentile. A vow of fidelity or abstinence is also a form of sacrifice, since it represents a permanent restriction of activities. Years of volunteer activity required of Mormons can be though of as a sacrifice of time, especially considering the foregone opportunity to accumulate human capital. Years of study in a religious institution represent a sacrifice of the alternative potential use of that time, be it in accumulation of human capital in secular studies or in accumulation of earnings.

Limiting choices and destroying resources is puzzling to an economist, yet people voluntarily join groups which enforce prohibitions and require sacrifices. These groups stubbornly defy price theory, persisting in time-intensive activities like communal worship, Sabbath observance and dietary restrictions despite the historical increase in the shadow price of time. Strict sects show no sign of disappearing and those with the most demanding practices seem to be growing fastest. ${ }^{25}$ The modern Anabaptist traditions (such as the Amish, Mennonites

\footnotetext{
${ }^{24}$ Much of this discussion in this section draws on Berman [2000], which describes prohibitions and sacrifices among Ultra-Orthodox Jews in more detail.

${ }^{25}$ Iannaccone [1998] describes the growth of conservative sects worldwide (p. 1471).
} 
and Hutterites) are holding their own while Ultra-Orthodox ${ }^{26}$ Jewry, and Radical Islam are thriving, despite a multitude of time intensive requirements.

Iannaccone (1992) offered a creative solution to the puzzles of prohibitions and sacrifices, proposing that they are efficient institutions in the context of an economic club which provides services to members. This section presents a simplified version of his argument, discussing prohibitions and then sacrifices. Section IV extends the argument to cover militia activity.

\section{Efficient Prohibitions}

A social interaction model offers an explanation. Group members derive utility from (secular) consumption, $S$, and from time spent in religious activities, $R$, such as prayer and community service. They also gain utility from the level of a local public good $A$.

$$
\text { (1) } \begin{aligned}
U_{i}= & U\left(S_{i}, R_{i}, A\right) \text { for } i=1 \text { to } N \text { members, } \\
& U_{1}, U_{2}, U_{3}>0, \quad U_{11}, U_{22}, U_{33}<0 .
\end{aligned}
$$

Good $A$ is nonrival and excludable, making it a $c l u b$ good. Members get $A$ from either a government, $G$, or the "club," $C$, which uses hours of religious activity as an input. Public safety is an example of a pure public good which could be provided by government or by a club, perhaps as a religious obligation. Welfare services, schools, hospitals and mutual insurance are examples of excludable, partially rival activities commonly provided by religious communities.

$$
A=G+C\left(\left\{R_{i}\right\}\right), \frac{\partial C}{\partial R_{i}}>0 \text { for all } i .
$$

Members maximize utility subject to time and budget constraints. A fixed allocation of time, $T$, is split between the religious activity, $R$, and work hours, $H$,

$$
T=H_{i}+R_{i} \text {. }
$$

Income is earned from wages $\mathrm{w}$ and spent on consumption of the secular good, $S$, at price $p$,

$$
p S_{i}=w H_{i}=w(T-R) .
$$

A key point is that the club good $C$ is produced by voluntary donation of time by members. These donations are extremely common in religious sects. Since that voluntary activity generates positive externalities, competitive equilibrium will result in too little religious activity $R$, as illustrated in Figure 1. The labor supply curve to the right indicates the competitive equilibrium choice of work hours, $H=T-R$, at the wage $w / p$. The curve to the left indicates the efficient labor

\footnotetext{
${ }^{26}$ Revealingly, the Hebrew term for Ultra-Orthodox, Haredi, literally means "shaker" impling trembling before the Almighty, the same way the Shakers used the term.
} 
supply schedule that a social planner would choose. She would prefer less work and more religious activity (at $\left.R^{*}\right){ }^{27}$

$\frac{w}{p}=\frac{U_{2}}{U_{1}}+\frac{U_{3}}{U_{1}}=M R S_{R S}\left(R^{*}\right)+M R S_{A S}\left(R^{*}\right)$.

The competitive equilibrium choice of $\mathrm{R}$ ignores the last term, which reflects the positive externality.

A community without tax authority ${ }^{28}$ could achieve the optimal level of religious activity $\left(R^{*}\right)$ by imposing and enforcing prohibitions on types of secular consumption, thus inducing members to work less and spend more time at religious activities. One of Iannaccone's key insights is that religious prohibitions can be rationalized as extreme but enforceable forms of taxation on

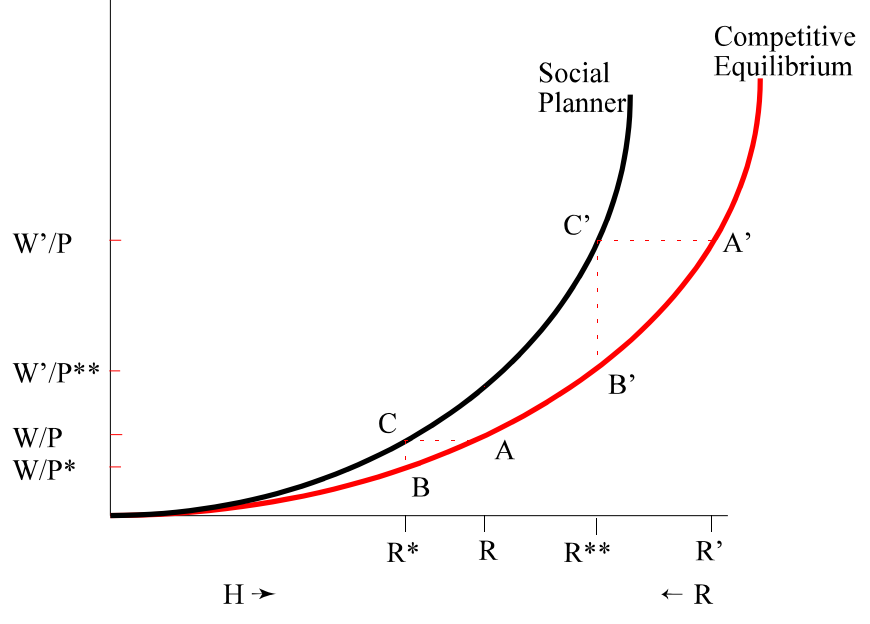

Fig 1: Optimal Taxation Through Prohibition secular activity. Individuals will voluntarily join a club which requires prohibitions. if the extra club good produced with the additional hours, $N x\left(R^{*}-R\right)$, is sufficiently valuable. More generally, contact with the secular world substitutes for club activities. Thus prohibitions that limit these outside contacts induce members to spend more time in religious and other club activities that have positive externalities. Exclusion from access to the local public good $C$ is a common, viable form of enforcement.

This argument can rationalize many forms of religious prohibition. For example, dietary restrictions increase the cost of market provision of food, while decreasing the ability of group members to socialize with nonmembers. Sabbath restrictions remove one's ability to driving to the mall and consume, inducing members to spend time together on the Sabbath instead, and so

\footnotetext{
${ }^{27}$ The level of A serves to amplify the labor supply elasticity in the upward-sloping segment of the labor supply curve (Figure I) if R and A are complements. A change in wages has both the conventional direct effect on leisure (hours worked) and an indirect effect in the same direction through its effect on A. This is the "social multiplier" effect emphasized by Becker and Murphy [2000].

${ }^{28}$ A community with tax authority would subsidize $R_{i}$, or tax the alternative use of time, $H_{i}$. Religious groups often encourage $R$ with eternal promises and the respect of one's peers. Yet $R$ may be hard to subsidize if it is unobservable, like anonymous charity. Alternatively, consider a community that can literally control the price level faced by members through a tax. To achieve the social welfare optimum they would lower the real wage by imposing a tax $J=p^{*}-p$, which induces a choice of $R^{*}>R$.
} 
forth. ${ }^{29}$ This also explains the attraction of dress codes, which aid enforcement by making community members readily identifiable. As in the military, being caught out of uniform triggers sanctions.

Adam Smith [1776] used the term "sect" to describe $18^{\text {th }}$ century Christian religious groups with strict practices. Sociologists use that term for groups that place strong restrictions on secular activities [Weber 1946, 1978]. Smith could just as well have been describing the birth of Ultra-Orthodoxy in the late $18^{\text {th }}$ century, or that of radical Islam in the early $20^{\text {th }}$.

Friction between club members and nonmembers resulting from a club's political agenda, for instance, may cause antagonism toward club members. That antagonism can be desirable and efficient for the club if it discourages outside activity by members. It provides another mechanism to induce higher levels of religious activity by reducing outside options. In that sense this is a theory of efficient intolerance. Efficient mutual antagonism between two clubs is an immediate extension. ${ }^{30}$

\section{Efficient Sacrifice}

Rationalizing prohibitions is important in understanding how radical religious sects operate, but our insights into militias will really flow from understanding sacrifices. Sacrifices are acts which irreversibly destroy value, like circumcision, burnt offerings, and ritual bloodletting. These cannot be rationalized as efficient prohibitions using the argument above since they do not tax a secular activity. They can be explained as an initiation rite which signals type [Camerer 1988, Iannaccone 1992].

To see how the model ${ }^{31}$ explains sacrifices, augment it with unobserved heterogeneity in the form of high wage (type 2) and low wage (type 1) individuals. High wage individuals choose less religious activity as it is relatively more expensive for them, i.e., $R^{2}<R^{l}$.

(Heterogeneity could alternatively be in both preference for religious activities at the margin and wages. Heterogeneity in wages alone is chosen mainly to simplify the exposition.) Assume that the value of the club good is given by the average of $R$, as would plausibly be the case in a mutual insurance club, where the average donation of time by members to mutual aid would matter.

$$
C\left(\left\{R_{i}\right\}\right)=C(\bar{R}), \quad \bar{R}=\sum_{i=1}^{N} R_{i} / N
$$

High wage - low $R$ individuals are potential "free-riders." They would like to join the high $R$ club and benefit from their high average level of religious activity. Members of the high

\footnotetext{
${ }^{29}$ The logic is similar to an argument for the efficiency of restrictions placed by landowner/lenders on the access of sharecroppers to outside sources of credit. Limiting outside opportunities can preserve incentive compatibility in the presence of moral hazard or enforcement constraints (Ghosh, Mookherjee and Ray, 2000).

${ }^{30}$ While it could be efficient for each club, mutual antagonism may endanger innocent bystanders.

${ }^{31}$ This is a simplified form of Iannaccone's [1992] model.
} 
$R$ (low wage) club would rather not admit the high wage types, as the reduction in the average level of religious activity will reduce club quality. Since access to the externality is excludable, the high $R$ (low wage) group can rid their club of free riders problem by requiring a costly initiation rite, or sacrifice, which will successfully exclude low $R$ (high wage) individuals from joining, keeping $C$ high, at $C=R^{1}$. Unlike religious activity, $R$, the sacrifice benefits no one except through its role as a signal. Potential applicants are forced to reveal their type, which is otherwise unobservable, when they make a decision to sacrifice, or not to sacrifice, time.

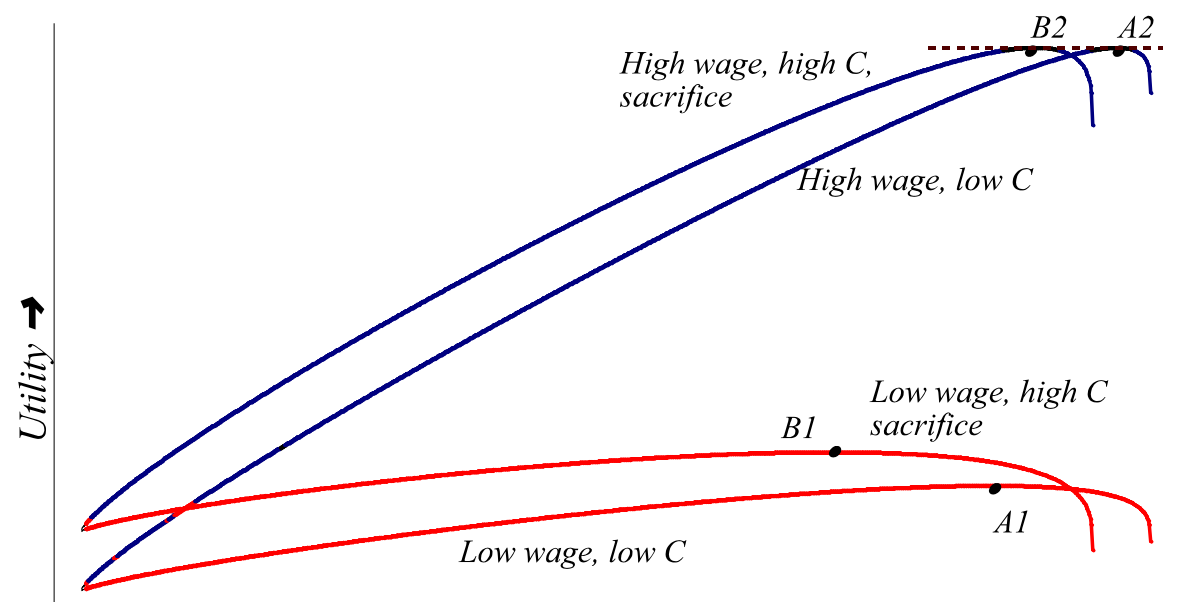

The gain to a club from requiring a sacrifice is illustrated in Figure 2. ${ }^{32}$ The horizontal axis shows the

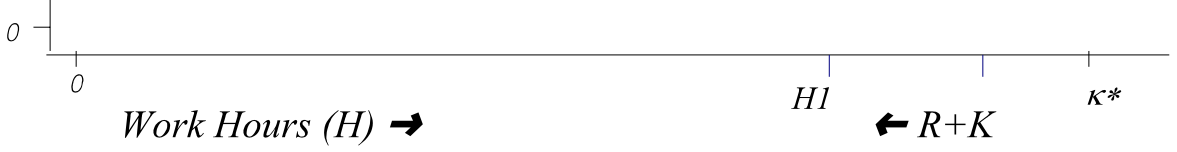

Figure 2. Efficient Sacrifice allocation of time between work hours, religious activity and sacrifice. The vertical axis measures utility. The two higher curves represent the utility of high wage types and the two lower curves the utility of low wage types. High wage types in a low $C$ environment choose point A2. Low wage types in a low $C$ environment choose A1 at a higher level of $R$ than high wage types. Low wage types improve their outcome by establishing a club which admits only members who sacrifice an amount of time 6*. By excluding high wage types they achieve the higher level of utility at B1, where the sacrifice of time is more than compensated by higher level of local public good $C\left(R^{1}\right)$.

A sacrifice inducing only low wage types to sacrifice is a separating equilibrium. The efficient sacrifice is the smallest $\sigma$ that induces separation, leaving high wage types indifferent between the high $C\left(R^{I}\right)$ and sacrifice (B2), and the low $C\left(R^{2}\right)$ without sacrifice (A2). The low wage, high $R$ group is better off with the institution of a sacrifice and will accept anyone who makes the sacrifice into the group, since a sacrifice reliably signals a high level of religious activity. This setup is analogous to other forms of costly sacrifices which signal type, such as initiation rites in the military, hazing in fraternities, Spence signaling in schooling, or frivolous engagement gifts.

\footnotetext{
${ }^{32}$ For a formal derivation see Appendix 1 in Berman (2000). Figure 2 is constructed by simulation using the function $U(S, R, A)=\left[S^{\$}+\left(R^{\prime \prime} A^{(1-1)}\right)^{\$}\right]^{/ \$}$.
} 
Applying this model to the behavior of radical Islamic groups yields some immediate insights. It allows us to rationalize the common Taliban practice of years of attendance in religious seminaries which offer little or no training in marketable skills. While indulging in the study of holy texts might not be surprising as a leisure activity for relatively wealthy individuals, it is a puzzling choice for impoverished Afghan refugees in Pakistan. Yet as a sacrifice of time which allows access to a desirable club, that behavior may be quite sensible.

The puzzling sacrifice among the Hamas is of a different nature. Members show a surprising willingness to risk arrest by organizing and conducting low level violent activity. Since arrest often implies protracted jail terms, this activity can also be understood as a sacrifice of time. Suicidal acts are not viewed as a sacrifice in this context. They are discussed briefly in the next section but are treated more completely in a companion paper (Berman and Laitin, 2003).

An extension of this model shows that subsidies to a club can induce extreme increases in sacrifice. Intuitively, if the subsidy augments the benefits of membership, the queue of potential free riders lengthens and a larger sacrifice is required to distinguish committed (low wage) from uncommitted (high wage) types. In the extreme case a subsidy can make club members worse off as the increased sacrifice outweighs the augmented benefits of membership. For details see Berman (2000). For the Taliban, such a subsidy could come in the form of transfers from their sponsors, Pakistani intelligence and Bin Laden or from increased revenues from controlling smuggling and the drug trade. For Hamas outside subsidies come mostly from the Gulf states and from the Palestinian diaspora. In both cases, subsidies exacerbate the free-rider problem by making the club more attractive, which in turn create a requirement for a more extreme signal of commitment, such as acts that trigger even longer jail sentences. 


\section{Militias}

Why do radical religious groups so often create militias and why are those militias so effective? Define militia activity as co-ordinated capture of rents involving violence. ${ }^{33}$ Attacking an occupying army, providing law and order, organizing and carrying out clandestine activity (such as terrorism) are examples. This activity often involves personal risk. A key aspect of militia activity is its sensitivity to defection. This section argues that religious sects have an advantage in militia activity because the signaling mechanisms adopted for the provision of other public goods allow them to select members unlikely to defect in a militia.

\section{Securing a Trade Route}

Consider a standard assignment in the imposition of law and order, securing a trade route. Imagine a road with $N$ checkpoints at which a convoy can easily be robbed, perhaps from Pakistan to Turkmenistan on the Kandahar-Herat route. The convoy is worth B at the last stop but worth nothing at the first, to emphasize returns from trade.

\section{Convoy}

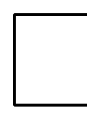

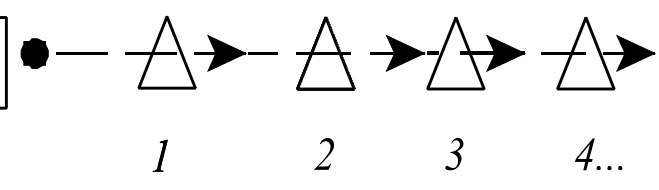

Checkposts
Destination

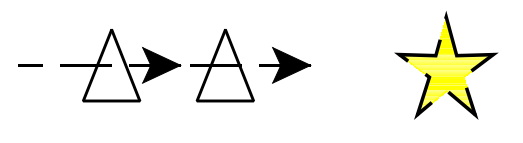

..N-1 $\quad N \quad \$ B$

Figure 3: Securing a Trade Route

A club member at each checkpoint allocates time to either $R$ or $H . R_{i}+H_{i}=1$ and $R_{i}$ is binary. Member $i$ can either "defect" $\left(R_{i}=0\right)$ and steal $B$ or remain "loyal" $\left(R_{i}=1\right)$ and protect $B$. The public good technology is

$$
\text { (4) } C(\{R i\})=C\left(\prod_{i=1}^{N} R i\right) \text {, }
$$

where $C(1)$ is the value of a safe road and $C(0)$ is that of an unsafe road, so that $C(1)>C(0)$. This multiplicative technology for joint production differs from the club's technology for producing benign local public goods, which averaged the $R_{\mathrm{i}}$, in equation (3).

A convoy will choose to set out only if all $R_{\mathrm{i}}$ equal 1 , which is to say each member remained loyal. In that case the convoy reaches the last stop and the club extracts the entire surplus $B$ which it shares equally among members, each receiving $B / N P$. If member $i$ defects he would keep the entire surplus $B$, loses access to the safe road (the public good $C$ ) as punishment,

\footnotetext{
${ }^{33}$ Violence is not an inherent feature of rent-seeking activities. It is more a symptom of the lack of a government which prevents negative sum activities such as violence. Terrorism, discussed below, is an extreme case.
} 
but earns the outside option wage $w_{i}>0$. That member will remain "loyal" if the following incentive compatibility constraint holds:

$$
U\left(\frac{B}{N P}, 1, G+C(1)\right) \geq U\left(\frac{B+w_{i}}{P}, 0, G\right)
$$

Taking the terms in the utility function in order, a loyal member has lower consumption than a defector $(B / N P<(B+w) / P)$ but gains the direct utility from doing his (religious) duty $(R=1)$ and has access to more of the local public good since $G+C(1)>G$.

If incentive compatibility fails, the result is an N player prisoner's dilemma, implying an unsafe trade route, no convoy and no rents to extract.

Now consider heterogeneity and adverse selection. Assume two unobserved types, high wage and low wage (as above) and assume parameter values such that low wage types remain loyal and high wage types defect. (I.e., there exists a $w^{\prime}$ such that $w^{L}<w^{\prime}<w^{H}$ and incentive compatibility in (5) holds only if $w_{i}<w^{\prime}$.) A club with a costly sacrifice as an initiation rite which successfully excludes all high wage types can consistently secure the trade route and extract the rent, B. A militia that cannot exclude high wage types will fail to secure the route.

Figure 4 illustrates how the maximum project value $B$ is higher for militias who can exclude high wage members. Militias prefer lower wage members because they are less prone to defection. The Figure graphs utility against project values for both defectors and loyal members.

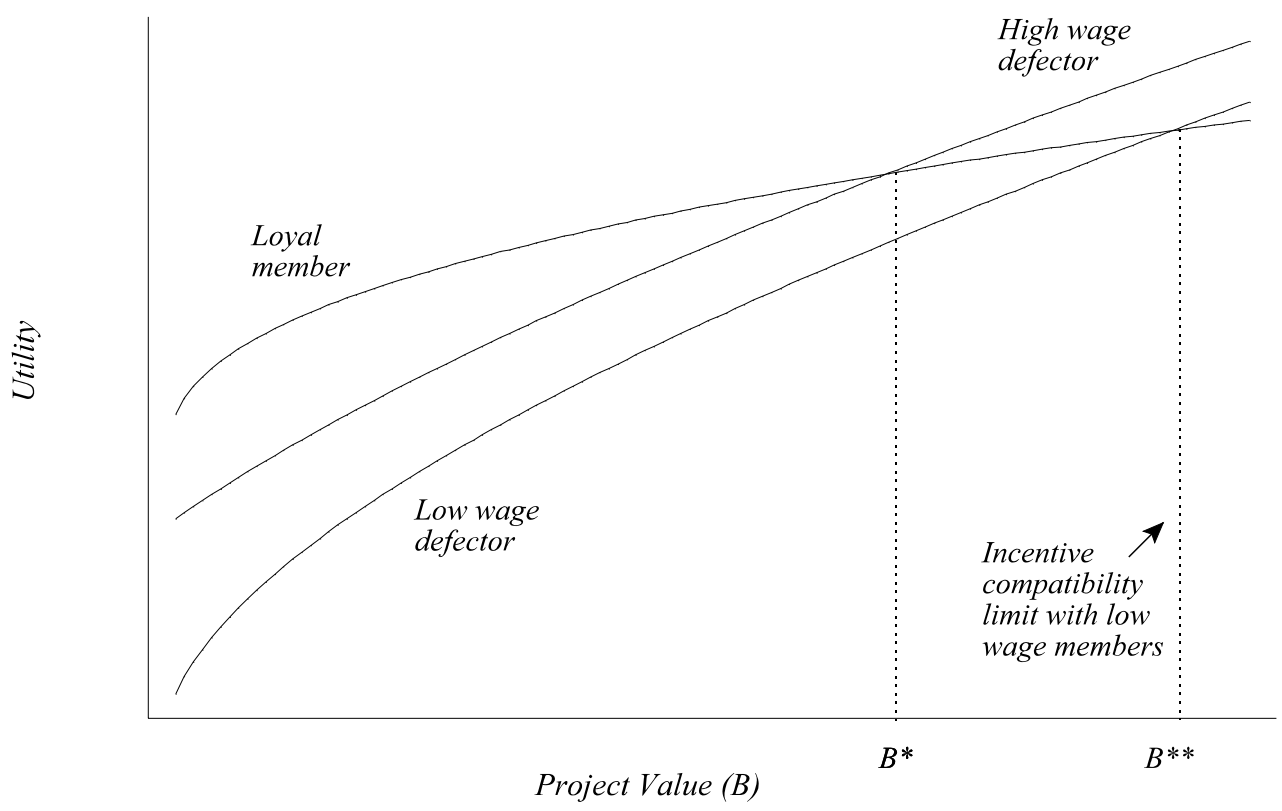

Figure 4: Low Wage Membership Allows Larger Projects 
Since loyal members $\left(R_{i}=1\right)$ earn no wages, their utility is unaffected by their wages. High wage defectors have higher utility than low wage defectors at all project values. In the interval $\left(B^{*}, B^{* *}\right)$ high wage members will defect while low wage members will remain loyal. This could explain the advantage of building a militia of young men with little labor market experience who were educated in the Maddraseh of Afghan refugee camps, rather than choosing combat veterans from among former Mujahhedin. It may also explain why, once formed, the Taliban were such a successful militia. ${ }^{34}$

In Afghanistan, this approach resolves the puzzle of how the inexperienced Taliban successfully secured trade routes for Pakistani interests while combat-hardened warlords and former Mujaheddin could not. Groups less adept at extracting signals of commitment (sacrifices) may not be able to consistently enforce incentive compatibility. The more radical the religious group in its norms of sacrifice, the tighter lower the effective outside wages of members and the more capable it is of imposing public order in the face of possible defection by members.

The multiplicative technology in (4) generally describes a wide variety of militia activities in which success is critically dependent on the loyalty of all members. Moreover, in cases where members endanger themselves, survival may depend on the loyalty of others. Consider two further examples of militia activities: co-ordinated assaults and clandestine attacks.

\footnotetext{
${ }^{34}$ The model is presented as static for simplicity. A more realistic dynamic version, under standard assumptions, would give a similar incentive compatibility constraint: Assume an infinite horizon, with a timeconsistent club strategy of never forgiving defection, and a defector smoothing consumption by consuming $r B+w_{i}$ each period for some rate of interest $r>0$. In a stationary equilibrium the future for a loyal member always looks the same, and the incentive compatibility constraint is just like (5) but with ' $r B+w_{i}$ ' replacing ' $B+w_{i}$ ' on the right hand side. The results in the rest of the paper for the static case follow as long as $r>1 / N$. The only clear insight the dynamics yields is that high $r$ and high $\mathrm{N}$ weaken incentive compatibility (good investment opportunities, longer expected lifetimes). Time inconsistency by the club may also weaken incentive compatibility through the prospect of future forgiveness.
} 


\section{Co-ordinated Assault}

Another example of militia activity relevant for Afghanistan is co-ordinated assault. Here soldiers (or units) attack some target by alternating between advancing and providing cover fire. A defection by the unit providing cover fire leaves other units exposed to fire from the target, causing the assault to fail.

Assume that

the target is worth $B$, both to the attacker and to the potential victim. Assume also that $\mathrm{B}$ can be divided as income among attackers (as would literally be the case for mercenaries). The potential victim will be willing to pay up to $B$ to induce defection. In Afghanistan there was a going rate to buy defections of this type. A successful assault is a club

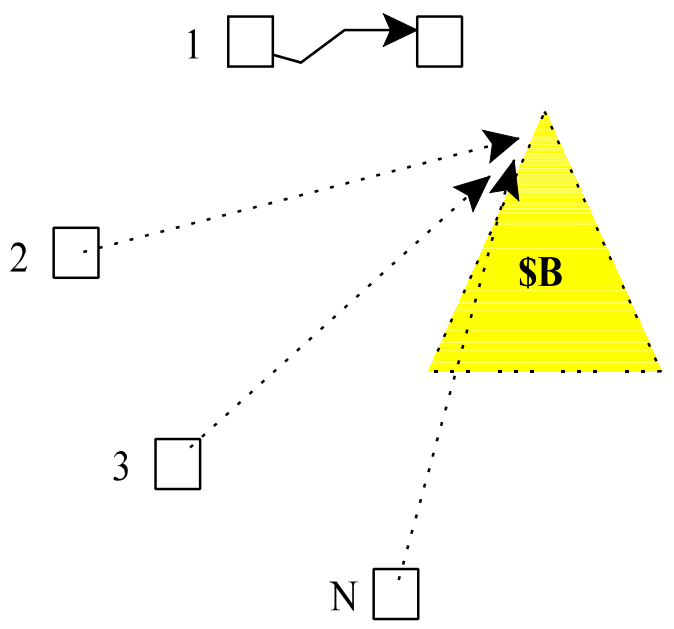
"good" to members, perhaps because it rids them of some occupying enemy, enhancing their quality of life. The analysis is then formally identical to the trade route case above, with militia production described by equation (4), the same payoff structure and an assault succeeding only if the incentive compatibility constraint (5) holds. ${ }^{35}$ If (5) fails, no assault is carried out and no rent is captured.

This approach can explain the remarkable fact that the Taliban was more successful at conquering Afghanistan than more experienced, larger, but less radically Islamic former Mujaheddin. It was easier to ensure the commitment of Taliban members because their extreme version of religious practice had signaled very limited outside opportunities $w_{i}$.

As an aside, this club approach may also explain the ascendancy of the Mujaheddin as an effective force in expelling the Soviets in the 1980s and early 1990s. While their religious practices were less extreme than those of the Taliban, they were much more extreme than those of the warlords who preceded them, who were not religious radicals.

\footnotetext{
${ }^{35}$ Considering the danger involved, we could relax the zero-sum assumption and allow the victim to lose more than B from an assault. That only worsens the defection problem as the victim will be willing to pay more than B to a defector.
} 
Guerrillas and Terrorists

Clandestine militias such as guerrillas and terrorists also share the multiplicative technology in (4). Consider an attack on some target where the potential victim can induce defection at any stage in the process, from planning through til the attack. Any of $\mathrm{N}$ conspirators, including planners, can defect or remain loyal. (This may be a negative-sum activity as the replacement value of the damage to the victim, $D$, may far exceed the value to conspirators, $\mathrm{B}$, so that $B<D$, even if $B(D)$ is an increasing function.)

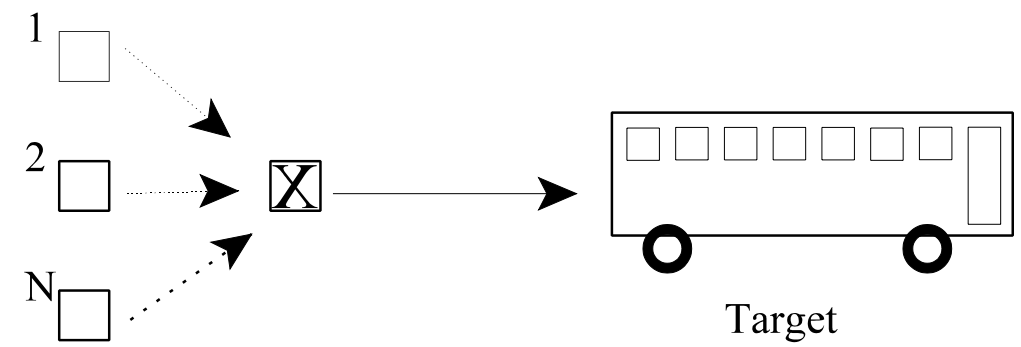

Conspirators

Figure 5: Terrorism

Assume that the $\mathrm{N}$ conspirators have nonrival benefit $\mathrm{B}$ from a successful attack. Assume also that conspirators have income from some outside sponsor (who values B). That income is small but proportional to $D$, " $D$, where $0<$ " $<1$. Assume for simplicity that a defector can extract the entire surplus, $D$, from the potential victim. In this case the incentive compatibility constraint for an individual member is

$$
U\left(\frac{\alpha D}{N P}, 1, G+B+C(\bar{R})\right) \geq U\left(\frac{D+w_{i}}{P}, 0, G\right) .
$$

As in the other examples of militia activities, a member remains loyal if the intrinsic value of doing his duty $(R=1)$, and the benefit of the extra local public good, $B+C(\bar{R})$, are sufficient compensation for the foregone income $((D+w) / P$ - " $D / N P)$ available to defectors. We assume that in this case the club is producing two local public goods. It uses the violent local public good production function in (4) to produce $B$ and the benign local public good production function to produce $C$.

Now consider again heterogeneity in outside options, $w$. Assume parameters are such that members with good outside options will defect while low wage types will not, (i.e., there is some cutoff wage $w^{\prime}$ below which (6) will hold and $w^{L}<w^{\prime}<w^{H}$ ). A club with the capacity to extract signals of commitment (low wages) can implement the clandestine attack technology 
(equation (4)) while other prospective militias cannot. This interpretation may explain why Hamas quickly became so effective at terrorist attacks, even without the experience of older groups with similar ideologies such as the Islamic Jihad.

Conspiracies evoke the painful topic of suicide attacks. Rationalizing the choices of terrorists on suicide missions is beyond the scope of this paper, and is discussed in Berman and Laitin (2003). In this context, though, it is worth pointing out that from the point of view of the controller suicide attacks are a particularly effective method of protecting conspirators, since the perpetrator cannot reveal information after the fact, removing a dimension of potential defection.

\section{Comparative Statics}

Figure 7 illustrates the relationship between the utility of defectors, the utility of loyal members and the value, $B$, of the convoy or target. Label $B$ the "project value" to generally describe the rent captured by various types of militia activities. If members sufficiently value the benefits of the club good and of the religious activity then at low project values it is easy to construct parameter values such that loyalty dominates defection. ${ }^{36}$ As $B$ increases, defection becomes more attractive till some maximum incentive compatible project size, $B^{*}$, where defection dominates loyalty. For larger projects than $B^{*}$ members will always defect.

Figure 7 also illustrates how any increase in the value of the benign club good, $C$, increases the maximum incentive compatible level of militia projects $B^{*}$.

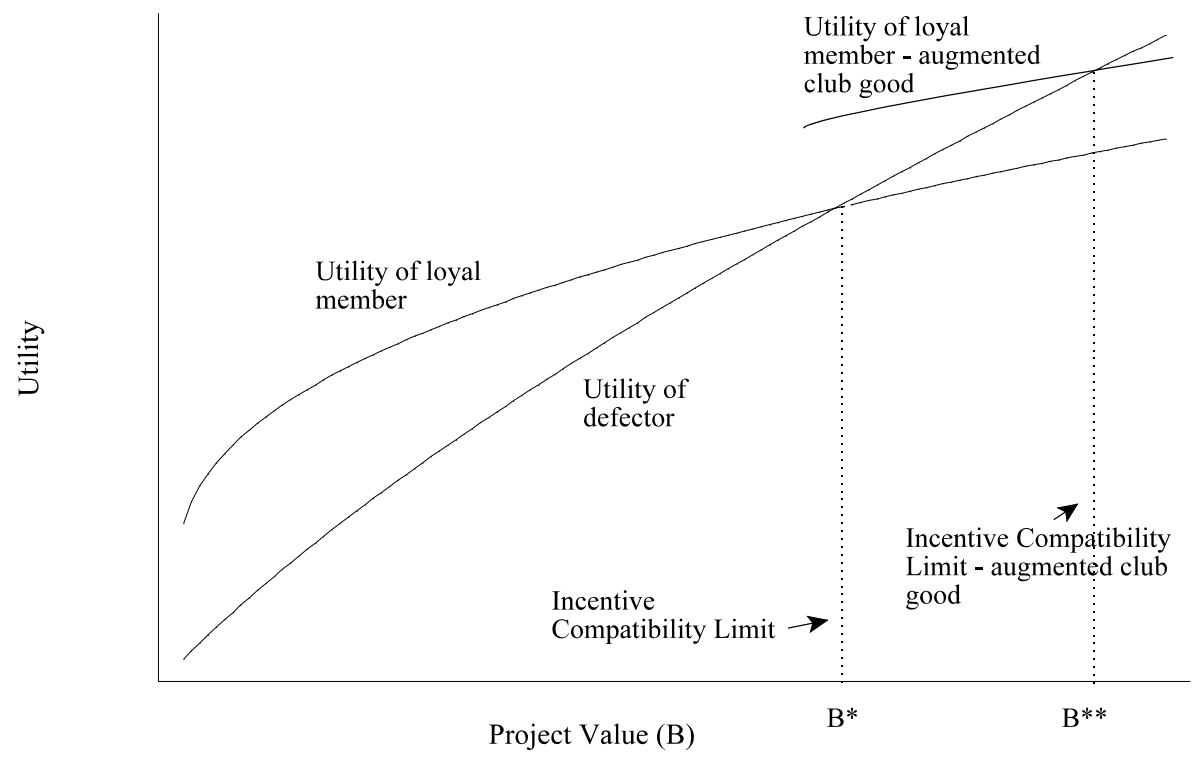

Figure 7: Benign Activity Increases a Militia's Potential Intuitively, a member who was on the margin of being bribed into defection at $B^{*}$ will be induced to remain loyal by the attraction of an increased value of the club good. A much larger potential bribe, $B^{* *}$, is now required to induce defection. Augmenting the club good may increase militia activity in two ways. First, for a given $B$ in the range between $B^{*}$ and $B^{* *}$, loyalty can be induced in equation (5) (or (6)) where it was previously absent, allowing rent

\footnotetext{
${ }^{36}$ The figures are simulated using utility function $U(S, R, A)=\left(S^{\$} R^{\$} A^{\$}\right)^{1 / \$}, \$=1 / 3$.
} 
extraction (in the convoy example) to increase from zero to $B$. Second, if the club can choose which projects to undertake, (i.e., convoys to allow on the road, hills to capture, targets to attack) it can now expand its range of feasible projects from $\left(0, B^{*}\right)$ to $\left(0, B^{* *}\right)$, capturing larger rents.

Thus clubs that are more productive at a benign club activity can exploit the induced cohesiveness by allowing themselves more militia activity in the sense of a higher project value $B$. In this way efficient provision of nonviolent club goods, such as health care, mutual insurance or educational services, complements the ability of these same clubs to function as militias. This may explain why Hamas is a more effective militia than Islamic Jihad which has a similar religious/national ideology, and much more experience at violent activity but provides less of the benign club goods.

The Figure also illustrates the effects of subsidies to clubs. A subsidy which augments $C$ or which provides cash payments to members can induce a discrete increase in militia activity for project values in the $\left(B^{*}, B^{*}\right)$ range. This may explain why even relatively small cash payments to families of suicide bombers, or small increases in the prestige that the public rewards those families with, ${ }^{37}$ can induce large increases in co-ordinated militia activity.

In contrast, the model predicts that increased provision of public goods by government will reduce militia activity. The mechanism is illustrated in Figure 8: Since the utility function exhibits diminishing marginal returns to public goods, increases in government provision of the public good $G$ makes potential defectors less desperate for the club good. This in turn diminishes the influence on members that the club derives from threatening to exclude their access to the club good. When government provides a high level of public (good) services, the maximum incentive compatible project value shrinks from $B *$ to $B^{* *}$.

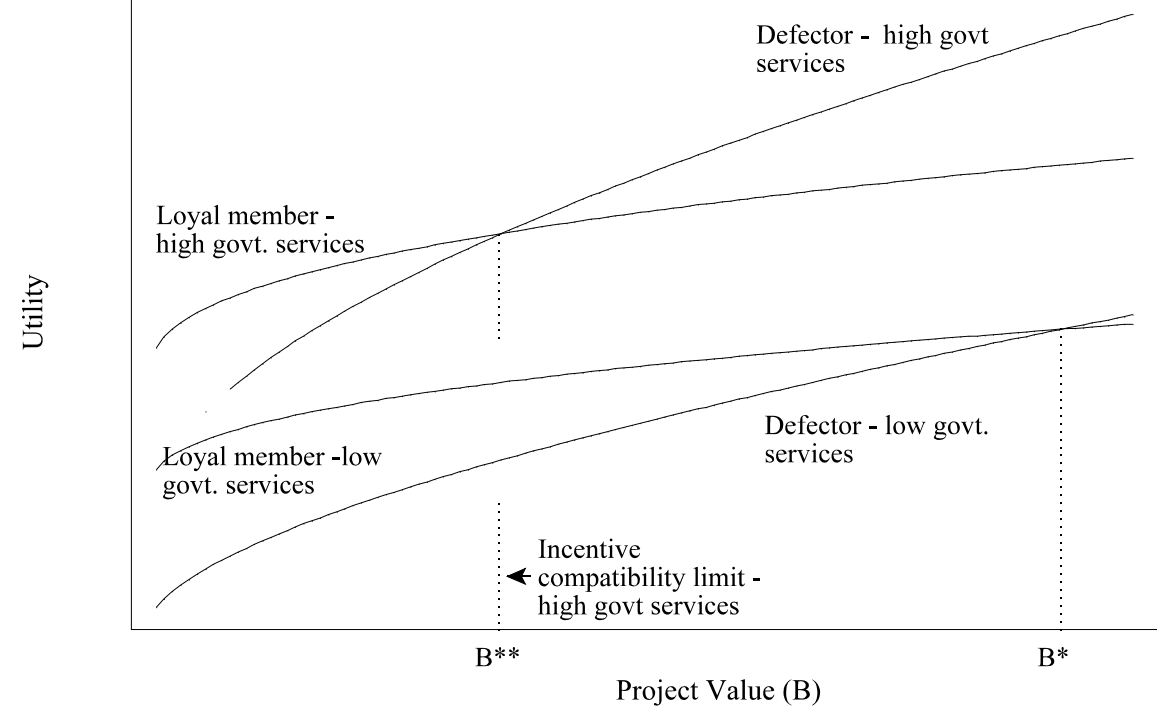

Figure 8: Government Provision of Public Goods Reduces Militia Activity

\footnotetext{
${ }^{37}$ Prestige could have the very concrete interpretation of preferred access to local public goods.
} 
In this context it is important to clearly define what we mean by government. In this model a government provides public good $G$ to both club members and to nonmembers without discrimination. Subsidies which increase $C$ increase militia activity by reinforcing incentive compatibility (club loyalty) and increasing $B$, the club's maximum feasible project. In contrast, subsidies to $G$, public goods accessible by both member and nonmembers, reduce militia activity since they improve the outside options of potential defectors, should they leave the club.

This policy prescription, improving public services to limit the influence of clubs, is actually not novel. It restates a proposal made by Adam Smith in the Wealth of Nations. In his discussion of Church and State he recalls religious violence in Europe and is concerned with the influence of $18^{\text {th }}$ century religious sects. He proposed that secular "gaiety" be subsidized in order to undermine the influence of sects with "disagreeably strict" moral codes.

Note that the only important characteristic of government in provision of local public goods is that $G$ be provided without discrimination to both club members and to nonmembers. Local public goods provided by nongovernmental organizations (NGOs) or foreign governments would also reduce the strength of militias as they do not favor club members. Symmetrically, a government that discriminates in provision of local public goods can in effect create loyal and less-loyal subpopulations, creating a potential advantage in organizing a militia among the loyal.

The comparative statics of equations (5) and (6), as illustrated in Figures 4, 7 and 8, can be summarized as follows: The maximum incentive compatible level of the target $B *$ increases in the value of the club good $C(1)$, and in the price level $P$; it decreases in the members' wage, $w_{i}$, in the level of government services $G$, and in $N$, the number of members sharing $B$. 


\section{Policy Options for Militias}

To the extent that a club can manipulate parameter values, it will aspire to efficiently increase its militia activity through both constructive and destructive acts.

\section{Constructive Efficiency:}

1) raising $C(1)$, through some other investment that augment club goods (welfare, hospitals, etc.),

2) making cash payments to members, (payments to families of martyrs),

3 ) investing in a technology to provide the club good with a lower number of participants, $\mathrm{N}$.

\section{Destructive Efficiency:}

4) lowering $w_{i}$, the outside options of members, (Madrasseh, jail time, secluding women, harassing nonmembers, destroying or banning access to Israeli labor markets),

5) limiting $B$ to keep it in the feasible range (ban on heroin cultivation),

6) reducing $G$, the public good available to members and nonmembers, (expulsion of NGOs providing humanitarian aid, closing schools and hospitals, assassination of judges and public officials),

7) raising $P$ (general strikes, access to goods markets).

Perhaps the most disturbing aspect of the club's incentives is that it is not only efficient for members to be self-destructive, it is even efficient for them to destroy the utility of nonmembers. The clearest mechanism is through the destruction of $G$. The explanation is the converse of the argument illustrated in Figure 8. At a lower general level of government services for nonmembers, potential defectors value the club good more at the margin, making them less likely to defect. That logic can explain the assassination of judges and public officials in Egypt by the Muslim Brotherhood, and harassment of humanitarian aid workers in Afghanistan by the Taliban.

A subtler mechanism by which the club benefits from damage to nonmembers is through its' effect in reducing outside options, $w_{i}$. The most difficult acts to rationalize by the Taliban are those that appear to be gratuitously destructive. One might expect that a religious organization intent on instituting a government based on ethical practices would attempt to make itself popular with the local population. Yet, the Taliban seemed to do their best to alienate the local population. They repeatedly massacred civilians [Rashid (2000), p. 70]. They beat women in Kabul, Herat and Jalalabad for the slightest offense, eventually secluding the women of Kabul in their homes with windows blackened to keep them out of sight. ${ }^{38}$ When humanitarian aid workers protested and threatened to cut off aid, the Taliban commanders reportedly implied that the seclusion of women was necessary in order to control their own troops [Rashid, p106, p111].

\footnotetext{
${ }^{38}$ Note the inconsistency with mainstream Islamic tradition. One of the Prophet Mohammed's first goals was to emancipate women.
} 
This type of destructive behavior can be interpreted as an attempt to lower $w_{i}$, broadly interpreted as the outside option of a defector. If a club member knows that he will find no sanctuary among the citizens he is policing, the outside option is compromised and incentive compatibility in (5) is strengthened. In contrast to other forms of destroying outside options, like sacrifices, self-mutilation or destruction of human capital, alienation of the local population imposes direct costs not on members but on nonmembers. The interpretation of gratuitous destruction among innocent nonmembers as an incentive is reinforced by the fact that Sharia restrictions were enforced more strictly in the conquered cities of Kabul and Herat than in the provinces or in the Taliban's home city of Kandahar (Rashid 2001, p. 40).

The same argument can be made at the level of a local governor. Afghanistan has a long history of warring factions and sub-factions defecting in return for some payment by an outside sponsor. The Taliban apparently had a practice of rotating local governors to the front or back to Kandahar if they seemed to be consolidating a local power base (Rashid, pp 101-103). Governors who alienated the local population fared better (Rashid, p. 105). That system could also be interpreted as a type of gratuitous destruction in which a governor's gratuitously harsh treatment of the governed population limits his outside option, $w_{i}$, reducing his incentive to defect.

Lowering $w_{i}$ took a much more literal form for Hamas members. From the organizations' inception in 1988 it distributed leaflets calling on Palestinians to stop working for Israeli employers, which would have amounted to an extreme sacrifice, especially among Gazans for whom day labor in Israel accounted for up to $40 \%$ of GNP. That demand was ignored by the general population and dropped at the time, though it was eventually achieved indirectly, when Israel responded to suicide bombings by closing access to her labor markets for Palestinian day workers. An important difference between Hamas and the Taliban is that Hamas is generally much more careful about alienating nonmembers, apparently limiting attacks when they are unpopular among Palestinians.

\section{Agenda Drift}

Referring back to Table I, the club good model with a militia technology can rationalize two puzzles: self-destructive behavior among club members, and behavior that appears to be gratuitously destructive toward nonmembers. (The latter category does not include acts of terrorism, which members view as club "goods" since they advance a collective political agenda.) What remains to be explained is the phenomenon of agenda drift, which I argued above was evidence against an ideological explanation for the puzzles of destructive behavior.

For both the Taliban and the Hamas, ideological shifts can be rationalized as a form of sacrifice. The Taliban ideology shifted dramatically and catastrophically over just a few years. It began with an emphasis on piety and local Islamic government as an alternative to brutal warlordism. As the Taliban gained territory, income and power, they became more extreme, welcoming payments from Bin Laden and Pakistan in exchange for establishing training bases for radical Islamic militias (Rashid, 2000). Their reported ideological support for Bin Laden's 
terrorist "Jihad" on the West was so strong that they were willing to risk all of their accomplishments rather than deport him in the wake of the September $11^{\text {th }}$ attacks.

In the context of this model, the Taliban's catastrophic support for Bin Laden is not puzzling if viewed as a mechanism of destroying the outside options of members. Once the Taliban controlled Afghanistan, defection would have required migration. What more credible way to destroy the outside option of stealing $B$ and establishing, say, a restaurant in Chicago, than declaring your absolute support for a global Jihad? In Figure 2, that sacrifice would appear as a downward shift in the utility of a defector necessitated by an increase in $B$. When viewed in this way, it is not surprising that in October 2001, despite the pleas of their Pakistani sponsors, there was no serious discussion of deporting Bin Laden among the Taliban. Raising the issue would have suggested a predisposition to defect, inviting severe punishment. ${ }^{39}$

The establishment of the Hamas was in itself a sharp ideological shift in the stance of the Muslim Brotherhood in Gaza. Their traditional emphasis was on personal piety and the establishment of local Islamic government. While in their view all of Palestine should eventually be an Islamic state, that battle could wait till their primary goals were achieved. With the first Intifada in 1988, the Muslim Brotherhood feared losing support to the PLO, their secular nationalist rivals, and so they took a strategic decision to establish a militia and violently oppose the occupation themselves. The Brotherhood could have opposed the occupation with minimal territorial demands such as those of the PLO and restricted their attacks to the West Bank and Gaza, which would have exposed their members and institutions to much less risk. Yet, they chose a large and expensive ideological shift, claiming as their goal the liberation of all of Palestine (including all of present day Israel) and carrying out attacks on civilians in Israel as well as in the occupied territories. That shift in ideology undoubtedly contributed to increased effort by Israel to arrest and detain militia members, resulting in years sacrificed in jail time.

This model can rationalize that expensive shift in ideology, again through the logic of incentive compatibility. While the Muslim Brotherhood is a conventional religious sect with a conventional club good technology $C\left(\left\{R_{i}\right\}\right)=C(\bar{R})$, the Hamas is a militia with the club good $B(\{R i\})=B\left(\prod_{i=1}^{N} R i\right)$ technology. Since the militia technology is much more sensitive to defection, it isn't surprising that the militia requires a much more expensive signal of commitment. The declaration by Hamas members of their intent to destroy the State of Israel would heighten the perceived threat to Israel and thus increase their expected amount of jail time sufficiently to provide the necessary signal.

\footnotetext{
${ }^{39}$ Perhaps revealingly, the Taliban foreign minister holding talks with Pakistan over a negotiated settlement remained in Islamabad rather than return to Kandahar.
} 


\section{APPliCATion: THE JEWISH Underground AND OTHER MiLitias}

The club model of religious militias is designed to explain the puzzles in Table I. Its relevance can be explored by examining its ability to explain the behavior of militias besides the Taliban and the Hamas. The Jewish Underground provides an instructive example because it successfully carried out small projects but when it attempted larger projects the conspiracy unraveled, exposing members to capture by the Israeli General Security Service and prosecution.

\section{The Jewish Underground}

The Jewish Underground was a violent militia which drew members from Gush Emunim, a messianic religious movement of orthodox Jews which established settlements in the West Bank and Gaza beginning in the mid 1970s. ${ }^{40}$ Members of Gush Emunim believe that in settling the holy land they hasten a messianic redemption of the Jewish people. Sociologist Gideon Aran identifies some sect-like characteristics of Gush Emunim,

"It is a whole culture as well as a self-sustaining community. The hallmark of an activistbeliever is not confined to a religious viewpoint or political stance; it also emerges as an encompassing system of behavioral norms which regulate all aspects of life, from housing patterns to leisure-time activities" [Aran (1991) p. 303]. Aran goes on to list a set of behaviors that distance members from the prevailing culture, including dress codes, amplified norms of worship, extended duration of Yeshiva attendance and a distinct educational system. Yet members of Gush Emunim are not nearly as extreme in their religious sacrifices or prohibitions, or in their mutual insurance activity or social service provision, as are Ultra-Orthodox Jews, for example. ${ }^{41}$

Most Gush Emunim members approved of aggressive vigilante activities against the local Arab population as a means of reducing stoning of their vehicles and other attacks. [Weisburd, 1989]. They considered vigilante activity a legitimate response in view of the failure of the government to provide adequate security to settlements. About a third of males in the early 1980s took part in some form of vigilante activity, which included threats, destruction of property, detention and sometimes shooting [Weisburd, 1989].

Opponents of the settlers saw these actions as attempt to provoke local Arabs and to pressure the military into suppressing stone-throwers [Aran, 1991]. Nevertheless, Gush Emunim settlers clearly felt that vigilante militias provided a local public good by enhancing their

\footnotetext{
${ }^{40}$ The Jewish Underground is well described by Israeli political scientist Ehud Sprinzak [1999] and by one of the members, Haggai Segal [1998], who wrote a book while imprisoned.

${ }^{41}$ More recently another Jewish terrorist group has organized on the West Bank, this time among a group closer to Ultra-Orthodox in practice. They attempted to detonate a bomb beside a girls' school in East Jerusalem in April 2002, are mostly Ultra-Orthodox from Bat Ayin, a small Jewish settlement outside Hebron (John Kifner, New York Times, May 8, 2002.) While the perpetrators of that act were convicted in September 2003, the Israeli GSS released other suspects in a related conspiracy which killed 8 Palestinians, for lack of an informant who would bring forth incriminating evidence.
} 
personal safety. Vigilante crimes were seldom successfully prosecuted, largely because investigators were unable to find witnesses who would offer incriminating evidence. ${ }^{42}$

In the aftermath of Anwar Sadat's visit to Jerusalem the prospect of Israel surrendering control of the West Bank and Gaza represented a threat to the messianic aspirations of Gush Emunim settlers. In desperation, a conspiracy involving about a dozen men was established in 1978 to carry out an incredible plot to detonate the Muslim holy sites on the Temple Mount / Haram A-Sharif. ${ }^{43}$ While the conspirators made careful operational plans they could not find a rabbinical authority who would authorize their project, and so they gave it up by 1982 [Sprinzak 1999, Segal 1978].

Following the murder by Fatah of six Yeshiva students in Hebron in 1980, leaders of the Jewish settlement in Hebron sought individuals "of deep commitment and dedication" to carry out a reprisal [Sprinzak, 1999], and turned to Menachem Livni, a leader of the Temple Mount conspiracy. The "Jewish Underground" planted explosives around the vehicles of three Palestinian mayors, maiming two (Bassam Shaka'a and Karim Khalef) and blinding an Israeli sapper sent to dismantle an explosive device. They also planted bombs in a mosque and at a local soccer field. Subsequently, in revenge of the murder of a Yeshiva student, the Jewish Underground murdered three civilian students in the Islamic College in Hebron in 1983.

The Islamic College killings were their first and last. The Israeli General Security Service (GSS) had already obtained the identities of conspirators from a settler who had been approached by the underground, had refused to participate and had subsequently applied to work at the GSS, his outside option. ${ }^{44}$ The GSS applied surveillance (and perhaps used an informant) and caught the conspirators planting bombs in four civilian buses in East Jerusalem in $1984 .{ }^{45}$

The Jewish Underground provides an example of a militia that overreached its grasp, attempting a project too destructive for its constituency to support. In terms of Figure 4, it could be interpreted as choosing a project with $B>B^{*}$ (the maximum incentive-compatible level), thus inviting an informant to defect. While their recruiting base, the settler population, was generally supportive of vigilante violence, it balked at murdering civilians and could be induced to report

\footnotetext{
${ }^{42}$ Sprinzak[1999, p. 169] discussing the report of deputy attorney general Yehudit Carp.

${ }^{43}$ The conspirators believed that this crime would trigger redemption (or at least halt the peace process) by either clearing the way for a Jewish temple to be built on the site of the ancient temple, or perhaps by triggering an Armageddon-like conflict with Islam which would force messianic intervention. No branch of Judaism condones acts which would blackmail the Almighty into dispatching the Messiah.

${ }^{44} \mathrm{He}$ inadvertently tipped off the GSS during his entrance interview and was tricked into revealing the information [Segal, 1988].

${ }^{45}$ Twenty eight members were subsequently convicted in connection to the different operations.
} 
(or tricked into reporting) those activities to the authorities. ${ }^{46}$ The leadership of Gush Emunim subsequently split, with the mainstream denouncing and repudiating the Underground. Among settlers the Underground fiasco contributed to the political maginalization of Gush Emunim.

Note that the Jewish Underground did not fail for lack of individuals who had a religiously motivated inclination toward violence. Acting alone, Baruch Goldstein massacred 29 civilians at prayer in 1994. Yigal Amir, apparently in conspiracy with only his brother, assassinated Prime Minister Rabin in 1995. The Underground failed because they could not consistently induce loyalty among members privy to their secrets. Projects as massive as the September 11th attacks, the Temple Mount assault or the conquest of Afghanistan apparently require not only motivated individuals but also the co-ordinated actions of a militia, in which incentive compatibility (i.e., loyalty) is crucial.

\section{Implications for other groups}

Turning to other groups, the model clearly implies that radical religious militias will be active when government provision of public goods is weak and when nonmilitia market opportunities are poor. While a comprehensive study of cases is beyond the scope of this paper, that seems to be the case in the Muslim world currently in Somalia, Nigeria, Algeria, Chechnya, Afghanistan, Kashmir, Tajikistan, Yemen, Bosnia and the Philippines. Radical religious militias have especially thrived during periods of weak government in Lebanon, Afghanistan and Egypt. Collapse of Soviet government authority was accompanied by an increase in radical Islamic militia activity throughout Central Asia, just as the collapse of Tsarist Russia was seven decades earlier (Rashid, 2002). Saudi Arabia is an exception: a country with generous provision of local public goods but an active radical religious militia nonetheless.

The militia model also implies that subsidies to militias can dramatically increase not only militia activity but also the intensity of prohibitions. That has been true in Afghanistan since the early 1980s, when massive Saudi and Western subsidies to the Mujaheddin apparently turned a relatively secular population into radical Islamists, long before the organization of the Taliban. Similarly, subsidies from Iran have exacerbated radical religious practice and militia activity by Hizbullah in South Lebanon.

\footnotetext{
46 The so called "New Jewish Underground" may prove to be more difficult to infiltrate and shut down, as its members are much closer to Ultra-Orthodoxy. At this writing it has attacked a number of Palestinian civilians and attempted to detonate a bomb out side a girls' school east of Jerusalem. The Israeli police have made numerous arrests but are having trouble gathering sufficient evidence to prosecute.
} 


\section{Policy Implications}

This economic model of radical Islamic militias has clear policy implications that flow directly from the analysis of incentive compatibility conditions (5) and (6) and the discussion of Figures 4, 7 and 8. Any intervention that weakens incentive compatibility will lower $B^{*}$, the maximal project value that a militia can undertake. Thus, a government which wanted to reduce militia activity, increase attrition from militias and reduce self-destructive sacrifices by members could:

A. reduce subsidies to clubs operating militias which are spent on services provided only to members, i.e., lowering $C$;

B. improve alternative provision of local public goods accessible to both members and nonmembers, i.e., raising $G$;

C. reduce smuggling rents and other rents that clubs operating militias can aspire to capturing, i.e., limit access to $B$;

D. improve outside options, i.e., raise $w$.

It is worth stressing the contrast between outside subsidies to club goods and outside subsidies to government-provided public goods. While both increase the flow of public goods to the local population, subsidies to clubs can create an incentive to increase militia activity. The critical difference is that government provision of public goods is nondiscriminatory, in the sense that it is not conditional on some (possibly destructive) norm of behavior required by the club of members. ${ }^{47}$ For that reason raising $C$ increases militia activity, as it increases the leverage clubs have with members, while raising $G$ reduces the influence of clubs by making them less dependent on club services, reducing militia activity. Thus, outside subsidies to governments will reduce militia activity if those governments provide services in a nondiscriminatory manner to all residents. Nondiscriminatory provision of services by NGOs would fill the same function.

This raises the following dilemma faced by foreign aid organizations and well-meaning foreign governments (Keating, 2001): What if the "government"behaves like a club, limiting public good provision to loyal members, as the Taliban generally did? Then there is no essential difference between aid to the "government" and aid to the club. Any transfer which increases the leverage of that government with members has the potential to increase destructive behavior as long as the governing club has the concern with defection expressed in equation (5). In Palestine and especially in Afghanistan, aid organizations and NGOs attempt to provide nondiscriminatory transfers (of food, education, health and welfare services) to a needy population. Militias, historically including the Taliban, try to capture those transfers to increase their influence as clubs. This situation places the humanitarian organizations and the militias in an inevitable conflict, as aid, $G$, weakens the influence of the club. In extreme cases the Taliban chose to halt aid to an impoverished population rather than agree to nondiscriminatory application of that aid.

\footnotetext{
${ }^{47}$ That is literally true only in the model. Efficient governments often do exclude access to public goods as a means of law enforcement, but have less distortionary sanctions at their disposal as well, such as taxes and an impartial judiciary.
} 
The model indicates no solution to this dilemma as long as a single club has the power to block aid (G) as the Taliban did. In the case of multiple clubs which act as discriminatory aid distribution organizations, it may be possible to create competition between them. That competition could bid down the "price" of access to aid which is paid by recipients in conforming to norms of prohibition and sacrifice. Unfortunately, that competition could also become violent.

Another course of action for foreign powers who want to weaken militias is to reduce economic rents, $B$, available to be captured. In the Afghan case many of these rents are due to the drug trade and the returns to smuggling caused by high duties and tariffs. For example, any reduction in demand for heroin in Europe, the primary destination of Afghani opium, would reduce rents available for Afghan militias to capture. As another example, a particularly distorting institution was the Pakistani-Afghan agreement on goods imported in bond. Goods bound for Afghanistan could be imported into the Pakistani port of Karachi free of Pakistani duties and tariffs. They were then trucked legally into Afghanistan and almost inevitably smuggled back into Pakistan, creating rents for Afghan smugglers and militias (Rashid, 2000).

Recent Egyptian history provides an instructive example in weakening militias. Though Gamal Abdel Nasser rose to power by creating a partnership with the Muslim Brotherhood the alliance was short-lived. Feeling threatened, Nasser not only imprisoned the leadership but nationalized the Brotherhood's well developed social service provision network (Munson, 2002). The subsequent decline in Brotherhood activity, both violent and benign, is consistent with models' prediction that the provision of benign local public goods is an essential part of the organization.

Farther afield, limiting the ability of a club to provide benign local public goods, such mutual insurance, was apparently part of a successful British policy to combat insurgency during the imperial period. For example, the communist insurgency in Malaysia was apparently controlled by aggressively enforcing a British monopoly on both violent and benign local public good provision. The British managed to stabilize the military control of their allies and eventually transfer power to those allies and leave peacefully.

The single most important tool in weakening militias may be improving the outside options of members in order to encourage defection. The PLO provides an example. When their Black September cell became a potential liability to the parent organization in the early 1970s, it was successfully retired by providing members with steady jobs, apartments and even brides in Beirut.

Strengthening outside options is a mechanism through which economic development can weaken militias, as appears to have happened in Northern Ireland. It is important to point out that economic development may be effective in weakening militias even if activists within a militia are not disproportionately poor, and support for militia activities is not disproportionately among the poor, findings reported by Krueger and Maleckova (2002a, 2002b). A club which is strengthened by its ability to provide local public goods may attract members for any number of 
reasons, and select leaders and combatants from among those members according to characteristics other than poverty. Returning to the September $11^{\text {th }}$ example, one would hardly expect Al Qaeda to send some of its' semi-literate mercenaries from a training camp in Afghanistan to flight school in Florida if there were some disaffected students in Europe available. In any case, the club good model focuses not on the popularity of the militia but on its effectiveness. The most effective militias $d o$ seem to require large infrastructures and a committed membership, which do seem to be disproportionately located in places with poor market opportunities and poor government provision of local public goods (e.g., Afghanistan, Palestine, Lebanon, Sudan, Algeria, Chechnya, Pakistan, Yemen, Bosnia and Kashmir).

These policy recommendations are not novel, yet they are strengthened by derivation from a model grounded in rational choice which can explain the behavior of radical religious militias. The model offers essentially constructive policies to limit militia activity. It suggests at the very least a two-pronged strategy for countering terrorists and militias. One prong would be conventional: intelligence, infiltration, deterrence and counterattack, including weakening the benign infrastructure of organizations like Hamas and Taliban which provide both benign and violent local public goods. The other would be constructive: economic development and aid to stabilize governments which provide local public goods in a manner that does not discriminate between club members and nonmembers. Self-determination could be one of those local public goods. The pervasiveness of radical religious sects currently providing social services throughout the world suggests that without a seriously constructive effort, the war on terrorism may be a long one. 


\section{CONCLUSIONS}

Can rational choice modeling help explain the effectiveness and destructiveness the Taliban, Hamas and other radical religious militias? This paper has argued that these puzzles can be explained by a club good model which emphasizes the function of these voluntary religious organizations as efficient providers of local public goods in the absence of government provision. This is the same approach that can rationalize the puzzling behavior of Christian religious sects (Iannaccone 1992) and Ultra-Orthodox Jews (Berman 2000). That model has clear policy implications.

It is efficient for these organizations to extract signals of commitment in order to prevent free riding in their mutual aid activity. Their expertise in extracting signals of commitment makes these nonviolent sects excellent potential militias, since commitment of members is crucial to militias, which can be easily compromised by defection. This approach can also rationalize seemingly gratuitous acts of violence of group members toward themselves and toward others. These destructive acts erode the outside options of members, making them more committed agents of the militia.

Destructive and even self-destructive militia activity can be explained by a rational choice model. This is hopeful news for policy interventions based on constructive incentives. The recommended policies are intuitive: economic development and support for governments that consistently provide basic social services, including law and order in a nondiscriminatory manner.

One might ask, if the model is so compelling, why did radical Islamic militias spring up in the $20^{\text {th }}$ century, but not earlier? Standard microeconomic theory would predict a decline in time-intensive religious activity as wages increase. Berman (2000) addresses this apparent paradox, arguing that signaling behavior was not necessary in the absence of a strong outside option to the club in provision of mutual insurance and other local public goods. The advent of high wages in a modern secular economy threatens the club with selective attrition of its most able members. That threat increases the need to signal commitment in order to select out potential free-riders. In that sense, radical Islam is the backlash of a mutual insurance club against the threat that markets pose to their survival: namely wage opportunities which induce attrition of their most able members. That backlash creates a supportive environment for militias because it develops techniques of measuring commitment crucial to successful militia activity.

The other special characteristic of the last few decades is technological change in militia activity, particularly in terrorist attacks. New technologies allowing a small number of conspirators to do a devastating amount of damage and to publicize their act almost instantly have dramatically increased their ability to provide a public "good" to their constituency. Of course, small numbers reduce the risk of betrayal.

While the model does not directly address the recent phenomenon of suicide attacks, the logic of sorting through signals provides at least one relevant insight. Rational choice models struggle with suicidal terrorists. We tend to think that most people either do not believe that their self-sacrifice will be justified by the political return to their own group, are not sufficiently altruistic to carry it through, or do not believe in the hereafter. Imagine a population with a 
distribution of individual beliefs, a small minority of which are extreme or even pathological (a Timothy McVeigh, for example). In isolation from an organized militia, these individuals seldom do much harm, and when they do these acts are isolated and nonrecurring. Now imagine a provider of benign social services whose contact with that population allows it to observe signals of belief. That provider could then identify extremists and psychopaths for a militia, effectively harvesting the extreme tail of the distribution of beliefs. Once identified, organized and armed, that minority could cause recurring damage. Those ideas are pursued in a separate paper (Berman and Laitin, 2003).

This paper has tried to make the case for a functional, economic view of radical religious militias. It should not be understood as arguing that ideology and theology are not important, though their role has been omitted in the discussion in order to see how far a functional approach can take us. Incorporating ideology and militias with nonreligious ideologies is a subject for future research.

\section{Further Research}

Radical religious militias show broad similarities with secular organizations with violent rentcapture technologies. Street gangs and well-organized criminal organizations (such as the Hell's Angels) often practice self-destructive norms such as prohibitions on legal work. These groups often show behavior which is clearly misogynous or in other ways destructive of others, which could be interpreted as (efficiently) destroying outside options of members. Militias with nonreligious ideologies seem to thrive when they simultaneously provide benign and violent local public goods. The Khmer Rouge, the Vietcong, the IRA and the Sicilian Mafia are examples of that pattern. These topics, which economists have generally left to the tools of sociologists and anthropologists, might benefit from reexamination using the club good model.

One way to think about ideology within the context of this model is to introduce some political ideology, such as a desire for self-determination, into an individual's utility function as a public good that a government or club could provide. ${ }^{48}$ In this context a popular desire for selfdetermination strengthens a club (or government) which promises to provide that public good. This paper should not be understood as arguing that improving market opportunities alone will be sufficient to overcome a religious or ideological movement or a demand for political public goods. It does argue that a government which effectively provides public goods, both economic and political, will reduce the appeal and the effectiveness of violent militias.

Finally, public economics has generally adopted as a working assumption the classical liberal approach of Smith and Hume, assuming that individuals have a direct relationship with the state and with markets. This paper follows Iannaccone (1992) in arguing for an approach to public policy that takes seriously the more complex relationship that individuals have with clans, sects, tribes and other groups, which often mediate or compete with an individual's relationships with states and markets.

${ }^{48}$ Strictly speaking, self-determination would be a club good only if it is excludable, which is inconsistent with the Western democratic model but may occur nonetheless. 


\section{Policy}

In short, radical Islam has a problem with Adam Smith, not so much on ideological grounds but for practical reasons. An efficient market economy and a functioning secular state threaten the network of affiliations that support the internal economies of radical religious sects, which allow social service provision through tithing, donation of time and mutual insurance. Markets and functioning governments reduce the reliance of members on that sect for social services, reducing the influence of the sect on members.

The policy implications outlined in the paper for a war on terrorism flow from an understanding of the three forces competing to provide economic services to members of religious sects: the market, the government and the sect. When sects prevail they can potentially use their influence and information to run militias with deadly efficiency. They are efficient as militias because the cooperative provision of social services and cooperative militia operations turn out to be very similar activities. If markets and governments prevail, militias are weakened because defection to the secular alternative becomes more attractive. Militias become harder to organize and easier to infiltrate.

The models' recommendations are essentially constructive. A government wanting to weaken a religious militia should strive to replace the social services provided by the militia's parent religious sect with services provided by some combination of functioning markets, government, and nondiscriminatory NGOs. One method would be to weaken the benign infrastructure of a particular radical sect, but in order to innoculate against religious militias in general, the recommended method would simply be to develop a well-functioning market economy, with all the complexity and effort involved. 


\section{REFERENCES}

Aran, Gideon (1991) "Jewish Zionist Fundamentalism: The Bloc of the Faithful in Israel (Gush Emunim)" in Martin E. Marty and Scott Appleby (eds.) Fundamentalisms Observed (Chicago: University of Chicago Press, 1991).

Armstrong, Karen, The Battle for God (New York: Ballantine, 2000)

Aziz, Ahmad, Islamic Modernism in India and Pakistan, (London: Oxford University Press ,1967).

Becker Gary S. "Crime and Punishment: An Economic Approach," Journal of Political Economy, 76(2) 169-217, (March 1968).

Becker Gary S. and Kevin M. Murphy, "Social Forces, Preferences and Complementarity," in Social Markets and the Social Economy, (Cambridge: Harvard University Press, 2000).

Berman, Eli "Sect, Subsidy and Sacrifice: An Economist's View of Ultra-Orthodox Jews," Quarterly Journal of Economics, 115(3) (August, 2000).

Berman, Eli and David Laitin, "Rational Martyrs: International Evidence on Suicide Attacks," UC San Diego mimeo, (October 2003).

Berman, Eli and Ara Stepanyan, "Fertility and Education in Radical Islamic Sects: Evidence from Asia and Africa."

Ben-Porath, Yoram (1980) "The F-Connection: Families, Friends and Firms and the Organization of Exchange," Population and Development Review 6, 1-29.

Black, Antony (2001) The History of Islamic Political Thought (New York: Routledge, 2001).

Camerer, Colin, "Gifts as Economic Signals and Social Symbols," American Journal of Sociology XCIV (1988): S180-214.

Cornes, Richard and Todd Sandler The Theory of Externalities, Public Goods and Club Goods, (New York: Cambridge University Press, 1986).

Davis, Anthony "How the Taliban Became a Military Force," in William Maley (ed.) Fundamentalism Reborn? Afghanistan and the Taliban (New York: New York University Press, 1999).

Esposito, John, L., The Islamic Threat, Myth or Reality? (3 ${ }^{\text {rd }}$ edition) (New York: Oxford, 1999). Unholy War: Terror in the Name of Islam (New York: Oxford, 2002).

Faksh, Mahmud A., The Future of Islam in the Middle East, Fundamentalism in Egypt, Algeria and Saudi Arabia. Westport, Conneticut: Praeger, 1997.

Friedman, Menachem, The Haredi (Ultra-Orthodox) Society - Sources, Trends and Processes, Jerusalem: The Jerusalem Institute, Research Series \#41, 1991.

Ghosh, Parikshit, Dilip Mookerjee and Debraj Ray, "Credit Rationing in Developing Countries: An Overview of the Theory," in D. Mookerjee and D. Ray (eds.) Readings in the Theory of Economic Development, New York: Blackwell, 2000.

Greif, Avner, "Cultural Beliefs and the Organization of Society: A Historical and Theoretical Reflection on Collectivist and Individualist Societies," Journal of Political Economy, CII (1994) 912-950.

Hassan, Nasra, "An Arsenal of Believers: Talking to the 'human bombs.' " The New Yorker, November 19, 2001. 
Iannaccone, Laurence R. "Sacrifice and Stigma: Reducing Free-riding in Cults, Communes, and Other Collectives," Journal of Political Economy, C(1992), 271-291.

"Toward an Economic Theory of Fundamentalism," Journal of Institutional and Theoretical Economics, XV (1997), 100-116.

"Introduction to the Economics of Religion," Journal of Economic Literature, XXXVI (1998), 1465-1496.

Juergensmeyer, Mark. Terror in the Mind of God: The Global Rise in Religious Violence, (Berkeley: University of California Press, 2000).

Keating, Micheal, "Dilemmas of Humanitarian Assistance in Afghanistan," in William Maley (ed.) Fundamentalism Reborn? Afghanistan and the Taliban (New York: NY Press, 1999).

Kifner, John "Israel Arrests Settlers it Says Tried to Bomb Palestinians," New York Times, May 19, 2002.

Krueger, Alan B. and Jitka Maleckova, "Education, Poverty, Political Violence and Terrorism: Is there a Causal Connection? NBER WP \#9074, July 2002(b). , “Does Poverty Cause Terrorism?” The New Republic, June 2002(a).

Kuran, Timur, Islam and Economics, Chapters 3 and 4:"Islam and Underdevelopment," University of Southern California, unpublished manuscript, 1999.

Mishal, Shaul and Avraham Sela, The Palestinian Hamas: Vision, Violence and Coexistence (New York: Columbia University Press, 2000).

Munson, Ziad "Social Movement Theory and the Egyptian Muslim Brotherhood," Sociological Quarterly 42(4), January 2002.

Rashid, Ahmed, Taliban: Militant Islam, Oil and Fundamentalism in Central Asia, (New Haven: Yale, 2000). , Jihad: The Rise of Militant Islam in Central Asia, (New Haven: Yale, 2002).

Schiff, Zeev and Ehud Yaari, Intifada, The Palestinian Uprising: Israel's Third Front (New York: Simon and Schuster, 1989).

Segal, Haggai, Dear Brothers: The West Bank Jewish Underground, (Woodmere N.Y.: Beit-Shamai Publications, 1988).

Smith, Adam, An Inquiry into the Nature and Causes of the Wealth of Nations (Reprint of 1776 version) (New York: Modern Library, 1965).

Sprinzak, Ehud, Brother Against Brother: Violence and Extremism in Israeli Politics from Altalena to the Rabin Assassination, (New York: Free Press, 1999) "Rational Fanatics," Foreign Policy, September/October 2000.

Townsend, Robert M, “Risk and Insurance in Village India,” Econometrica, LXII(1994), 539-91.

Weber, Max, "The Protestant Sects and the Spirit of Capitalism," in H.H. Gerth and C. Wright Mills (translators and editors), From Max Weber: Essays in Sociology, (New York: Oxford, 1946).

, "Economy and Society (Berkeley, California: University of California Press, 1978).

Weisburd, David, Jewish Settler Violence: Deviation as Social Reaction," (University Park Penn.: Pennsylvania State University Press, 1989). 


\section{Table I: Summary of Sect Characteristics}

\begin{tabular}{|c|c|c|}
\hline & Hamas & Taliban \\
\hline $\begin{array}{l}\text { Local public } \\
\text { goods }\end{array}$ & $\begin{array}{l}\text { schools, hospitals } \\
\text { welfare, militias }\end{array}$ & law and order, militias \\
\hline Subsidy & $\begin{array}{l}\text { Gulf states } \\
\text { Muslim diaspora }\end{array}$ & $\begin{array}{l}\text { Saudi donations, } \\
\text { Pakistani intelligence } \\
\text { smuggling revenue }\end{array}$ \\
\hline $\begin{array}{l}\text { Gratuitous } \\
\text { destruction }\end{array}$ & general strikes & $\begin{array}{l}\text { subjugation of women, } \\
\text { homosexuals, } \\
\text { nonbelievers, } \\
\text { massacre of civilians }\end{array}$ \\
\hline Sacrifice & $\begin{array}{l}\text { risking arrest, injury or } \\
\text { death }\end{array}$ & madrassa attendance \\
\hline $\begin{array}{l}\text { Agenda } \\
\text { drift }\end{array}$ & $\begin{array}{l}\text { active nationalist } \\
\text { opposition to } \\
\text { occupation, } \\
\text { maximalist territorial } \\
\text { demands, } \\
\text { terrorism }\end{array}$ & $\begin{array}{l}\text { support for Bin Laden's } \\
\text { "Jihad" on West, }\end{array}$ \\
\hline $\begin{array}{l}\text { Militia } \\
\text { activity }\end{array}$ & $\begin{array}{l}\text { enforcement of strikes, } \\
\text { assassination of } \\
\text { informants, } \\
\text { attacks on Israeli } \\
\text { civilians and Israeli } \\
\text { military }\end{array}$ & $\begin{array}{l}\text { guarded smuggling } \\
\text { routes, } \\
\text { heroin trade, } \\
\text { conquered } 90 \% \text { of } \\
\text { Afghanistan }\end{array}$ \\
\hline
\end{tabular}

